\title{
Dansk Berlinerdreng i grænselandet
}

En folkelig og politisk læretid - erindringer 1920-1947

\author{
af Fr. Rudbeck
}

Fr. Rudbeck er født i Berlin i 1916. Fra 1947 var han fast knyttet til Sydslesvig-arbejdet, senest som Grænseforeningens landssekretær. Gennem årene har han skrevet utallige artikler og en hel række bøger. Her fortæller han om barndommen i Berlin og ungdomsårene i Nordslesvig frem til 1947.

At skrive sine erindringer er ikke altid så ligetil. Uvilkårligt tænker man: Har det, du har oplevet nogen som helst interesse for andre, og hvor meget husker man i grunden? Hvor meget af det, man har oplevet, står ikke i et mere eller mindre forklaret skær, og hvor meget af det, man mener at huske, skyldes mon en form for efterrationalisering?

Det følgende bliver beretningen om et broget livsforløb, præget og påvirket af slægtsbånd og af livet $\mathrm{i}$ grænselandet, ikke mindst mine år ved landbruget $i$ Sønderjylland. Det blev et liv, som i høj grad kom til at stå i grænselandets tjeneste. Jeg begyndte som Berlinerdreng og endte som Grænseforeningens landssekretær.

Jeg har valgt at dele denne beretning op $i$ to hovedafsnit. Først den tid, da grundlaget for mit politiske og nationale arbejde blev lagt, og derefter selve det arbejde, der navnlig efter 1947 blev min livsgerning, og som endnu ikke er helt afsluttet, selvom jeg er nået ind i pensionisternes rækker.

Her gengives mine erindringer om tiden frem til umiddelbart efter krigens afslutning. Til næste år bliver det forhåbentlig muligt at fortsætte med beretningen fra $1947 \mathrm{og}$ frem mod vore dage.

\section{Min slægt}

Rudbeck-slægten er en gammel sønderjysk slægt med rod i Vedsted sogn i det gamle Tørning Len. I 1547 overdrog hertug Hans den ældre i Haderslev den tidligere kongelige fæstegård Rudbæk til »sin kære tro Peter Hansen«, som var født i Hoptrup sogn. 
Gården Rudbeck ligger der stadig, lidt syd for Skovby og lidt øst for den nuværende motorvej, men også lige øst for Hærvejen, Oksevejen, den gamle jyske hovedvej til Mellemeuropa. Gården lå ned til Rudbækken, der løber under Immervad bro. Her var tidligere vadested og rastested for studedrifter. Nogle af de gamle rastepladser kan stadig ses.

Her lå også Immervad kro, og det var måske ikke helt tilfældigt, at hertugen på Haderslevhus anbragte en af sine tro folk i dette befærdede overgangssteds nærhed.

Det blev Peter Hansens sønner, som tog navnet Rudbeck. Den ene søn, Johan Pedersen med tilnavnet Rudbeck, udvandrede 1580 til Sverige, hvor han blev stamfar til den også "hinsedan« ret så udbredte Rudbeckslægt, hvoraf botanikeren Olof Rudbeck (1630-1702) blev særdeles berømt. En anden søn videreførte gården, og den har sandsynligvis været i slægtens eje i et par generationer. Men på et tidspunkt flyttede slægten til Sønderballe i Hoptrup sogn. Og i 1717 møder vi så den første Rudbeck på vor senere slægtsgård i Flovt i Øsby sogn.

På denne gård fødtes min oldefar Nikolaj Rudbeck, som i 1827 blev mand på gården. Han betegnes som en meget engageret bonde. I 1843 var han sammen med en bror, Hans Nissen Rudbeck i Grarup, medstifter af den forste slesvigske forening. Begge var også medstiftere af Skamlingsbankeselskabet. De hørte således til dem, der i de nationale brydningstider efter 1830 tidligt tog parti og meldte sig i kampen for danskheden i Sønderjylland og ikke mindst til bevarelse af det danske sprog. Vi ved også, at Nikolaj Rudbeck i 1864 var blandt dem, der bar den kendte sønderjyske leder Laurids Skaus kiste fra Mariegård til Gl. Haderslev kirkegård.

Min bedstefar fødtes i Flovt i 1853. Han købte i 1879 Mørcks Hotel i Haderslev, det senere Krauses Hotel på Sønderbro ned til Møllestrømmen. Han havde som dreng overværet Frederik VII's besøg på Harmonien i Haderslev. Efter Sønderjyllands afståelse til Prøjsen valgte han at optere for Danmark. Lige som så mange unge sønderjyder håbede han, at Nordslesvig som følge af $\S 5$ ville vende tilbage til Danmark, og hvorfor så først blive tysker? Han aftjente sin værnepligt ved Livgarden i København. Som optant var man altid udsat, og omkring 1890 førte en måske lidt vovet udtalelse om tyskerne til hans øjeblikkelige udvisning. Kun 48 timer havde han til at afvikle sine ting og sælge hotellet. Det var næppe efter hans smag, at det blev tyskeren Krause, han måtte sælge til. Min bedstefars gamle kærnedanske staldkarl Hans Knudsen nåede jeg som dreng at hilse på under et besøg i Haderslev.

Min bedstefar var landmåleruddannet. Nogle ældre mennesker kunne så sent som i 30'erne fortælle mig, at de huskede ham fra landmålingsarbejder på Haderslev Næs. 
I almindelighed rejste de udviste jo nordpå. Men bedstefar ville ikke miste forbindelsen til sin hjemstavn. Med kone og to børn rejste han til Prøjsens yderste hjørne, til Schlesien, og bosatte sig senere i Breslau, hvor han i kraft af sin landmåleruddannelse fik arbejde ved de tyske rigsbaner.

Senere flyttede han til Berlin. Her opnåede han i 1901 at blive prøjsisk statsborger. Dermed var vejen fri for at flytte til Nordslesvig igen, men han døde allerede i 1903. Min bedstemor, der ellers var fra Vamdrup, og hvis far havde deltaget i treårskrigen, kunne ikke få sig selv til at flytte igen.

I Berlin blev mine bedsteforældres hjem et slags fristed for adskillige nordslesvigere, der aftjente deres værnepligt i Berlin. Mange år efter, da jeg selv kom til at være alene i Nordslesvig, blev det nogle af disses hjem, som gav mig et fristed.

\section{Mine forældre}

Min far blev født i Haderslev den 24. september 1881. Han gik først i en af de i 1888 forbudte små danske privatskoler, Frk. Petersens skole i Slotsgade, hvor han sad sammen med senere kreditforeningsdirektør P. A. Callø, der kom fra Søndergård ved Erlev. Den sidste tid i Haderslev gik han i FriederichsSchule ved Gammelting, den senere jernbanestation, som nu er en del af byens kommunekontorer. Han har ofte fortalt mig om sine tyske lærere, som kunne være nok så strikse, når de danske elever holdt sig lidt for tavse, når tyske fædrelandssange skulle synges. Det kunne være fristende i stedet for »Ich bin ein Preusse« at synge »kein Preusse«.

Efter familiens flytning tog han studentereksamen i Berlin og siden var han på et studieophold i København, hvor han iøvrigt igen traf sin gamle skolekammerat P. A. Callø og ligeså Kresten Refslund Thomsen, den senere amtmand i Aabenraa.

Far fik en stilling på Rathaus Schöneberg, og da den var ret betroet, slap han for at komme med i Første Verdenskrig. I krigsvinteren 1916 gjorde jeg min entré $\mathrm{i}$ familien.

Som født i Haderslev var far stemmeberettiget til folkeafstemningen 1920. Min faster døde 1919 af den spanske syge. Men far kunne rejse hjem og afgive sin stemme. At han stemte for Danmark, herom hersker der ingen tvivl. Det gjorde ellers kun et fåtal af de sydfra kommende stemmeberettigede. Endnu kan jeg se far ved hjemkomsten stå af toget og omfavne sin mor med ordene: »Nu kom vi hjem til Danmark«. Derimod troede han ikke meget på Flensborg, hvor han havde været på besøg. Afstemningen her den 14. marts bekræftede desværre kun hans opfattelse. 


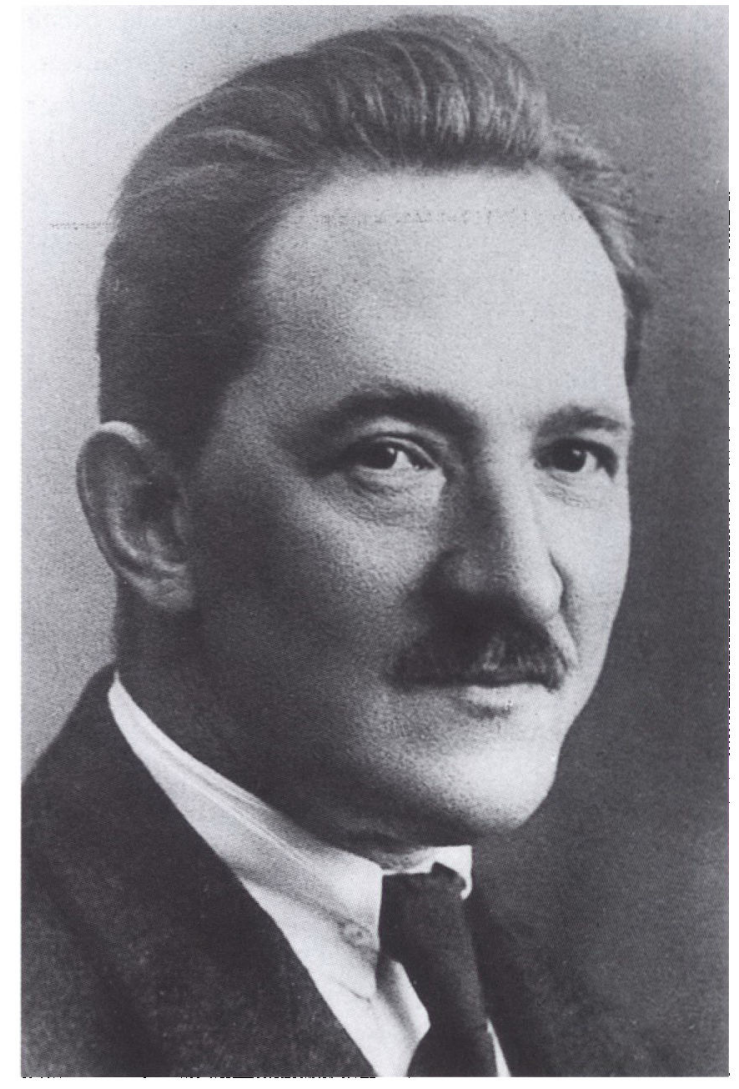

Frederik Rudheck (1881-1939). Foto ca. 1930 i privateje.

Vi blev indtil videre boende i Berlin. Far kunne heller ikke uden videre forlade sin stilling $\mathrm{i}$ rådhuset.

Under krigen var far blevet gift med en berlinerinde, født og opvokset i bydelen Moabit. Ligesom far var mor stærkt politisk interesseret, og sammen deltog de i mange partiarrangementer indenfor det tyske socialdemokrati, SPD. Far blev distriktsformand for SPD i Friedenau. Især husker jeg fra disse år de store 1. maj-demonstrationer med - set i mine øjne - kæmpe folkeoptog med masser af faner og musik, og selve festen i bryggeriets have i Schöneberg.

Mor og far fik en stor bekendtskabskreds. Fars partiarbejde og hans begyndende journalistiske virksomhed med artikler til danske blade gav ham mange gode kontakter helt op i de førende socialdemokratiske kredse. Tydeligt står for mig et besøg af Hermann Müller, der som tysk udenrigsminister i 1919 var medunderskriver af Versaillestraktaten og senere blev tysk rigskansler. Selv 


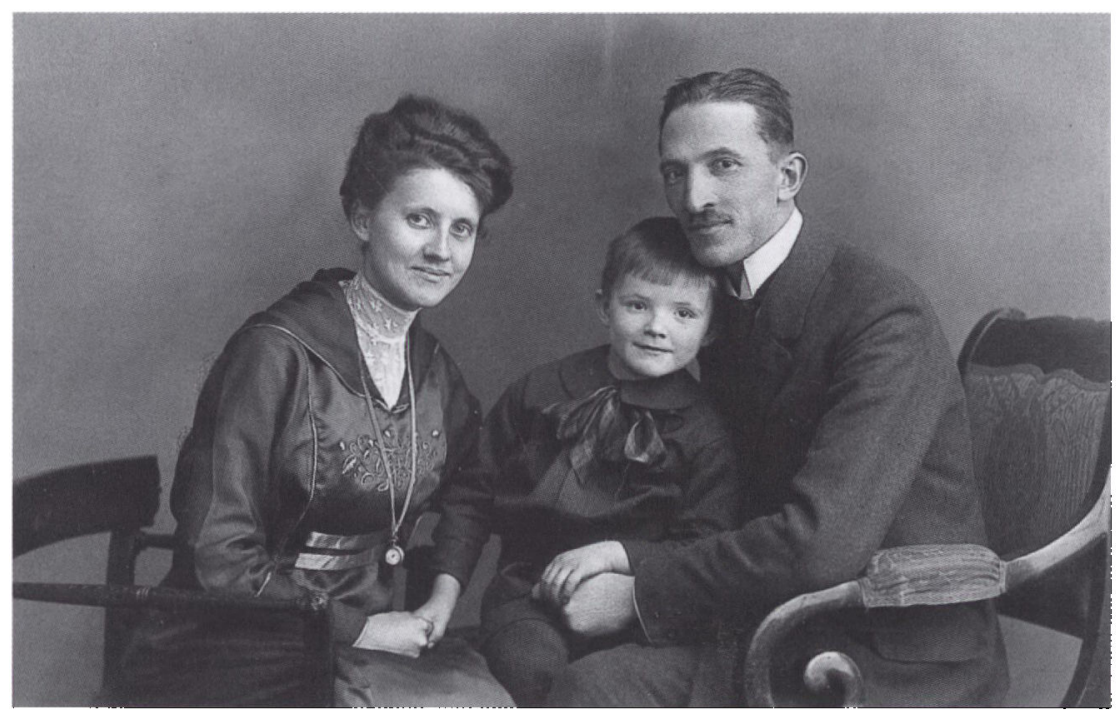

Familien Rudbeck fotograferet 1920 i Berlin-Friedenau. Foto i privateje.

om jeg ikke var ret gammel, står dette besøg og fars omtale af den kendte mand lyslevende for mig.

I sommeren og efteråret 1923 døde med få måneders mellemrum såvel min bedstemor som min mor. For en 7-årig var det næsten ikke til at fatte, at de to mennesker, som stod mig nærmest, skulle dø, mor endda $i$ en alder af kun 32 år. Mor var et kærligt menneske, som jeg følte mig stærkt knyttet til, betydeligt mere end til far, som jo havde så mange gøremål uden for hjemmet. Alligevel havde vi haft mange gode dage sammen. Det var svært at se, hvordan fremtiden ville blive.

Efter mors død følte far sig ret så alene i Berlin, og han imødeså med spænding det tidspunkt, hvor han kunne lade sig førtidspensionere og vende tilbage til sin hjemstavn. Vi måtte dog vente til 1927.

Allerede i sin berlinertid var far, ligesom hans far før ham, begyndt at skrive artikler til danske aviser. Det var især bladene Modersmaalet/Dannevirke i Haderslev han skrev til, men også "Politiken« og »Hejmdal« forsynede han med stof. Det var selvfølgelig mest tyske politiske forhold, han kommenterede ud fra sit republikansk-socialdemokratiske standpunkt. At han var dansker og socialdemokrat gjorde ham i de borgerlige tyske kredse til en mistænkelig person. Hans artikler blev fulgt nøje fra tysk side bl.a. af det tyske konsulat i Aabenraa. En af artiklerne fremkaldte en klage, der nær havde ført til hans afskedigelse. Han slap dog med en bøde. Så sent som i 1988 fik jeg bekræftet 
denne sag, da redaktør Siegfried Matlok overlod mig nogle kopier af akter, han var stødt på i det tyske udenrigsministeriums arkiver. De viste tydeligt, at fars hele danske indstilling absolut ikke var velset.

Efter pensioneringen i 1927 kunne intet hindre far $i$ endelig at flytte hjem. Vi bosatte os i Haderslev og senere i Årøsund. Nu kunne han skrive, arbejde med slægtsforskning og lokalhistorie i Øsby sogn og fortsat kommentere begivenhederne i Tyskland. Nu var han på den rette side, mente han.

Men det skulle gå anderledes. I 1932 fik han besked om, at han ikke længere kunne få sin pension udbetalt i Danmark. Kun når han bosatte sig i Tyskland, ville pengene falde.

Selv om han fik opklaret, at det alene skyldtes hans danske sindelag, og at tilstrækkeligt tysksindede godt fortsat kunne nyde deres pension i Danmark, og selv om H. P. Hanssen, med hvem far havde en ret nær kontakt, slog sagen vældigt op bl.a. i dagbladet Hejmdal, var der intet at gøre. I oktober 1932 flyttede han til Flensborg, hvor han, der egentlig aldrig havde interesseret sig synderligt for Flensborg og 2. zone, alligevel hurtigt kom ind i mindretalsarbejdet. Her fik jeg da også selv mine første kontakter med danske syd for grænsen, lidet anende hvad det siden skulle udvikle sig til.

Imidlertid strammedes jo kårene i Tyskland især efter Hitlers magtovertagelse i 1933, og det viste sig hurtigt, at fars danske fortid i Berlin og hans politiske holdninger med mange kontakter til endog ret fremstående tyske socialdemokrater aldeles ikke var glemt. Hans gamle sag fra Berlin dukkede op igen, men blev dog tilsyneladende henlagt. Foreløbig fik han lov at leve uantastet, men forsigtighed var tilrådelig.

\section{Drengeår $\mathrm{i}$ det gamle Berlin}

Selv om jeg af gode grunde ikke kan mindes afslutningen af Første Verdens$\mathrm{krig}$ - jeg var $2 \frac{1}{2}$ år, da kejseren forsvandt og krigen afsluttedes - har jeg en helt klar erindring om de svære og ofte urolige efterkrigsår, som fulgte.

Berlin havde været det tyske kejserriges metropol. Her var liv og spænding, og her lå mulighederne for de store oplevelser. Med sine 4 mill. indbyggere var Berlin er storby, en af verdens fire største. Det var samtidig en spændende by, hvor gammelt og nyt mødtes. Spændende var det opleve Alt-Berlin bag Alexanderplatz med de små gyder, med Berlins ældste værtshus "Zum Nussbaum «, med Parochialkirkens klokkespil og så kejsertidens Berlin med slottene, kirkerne og de mange mindesmærker bl.a. i Siegesallé og ikke at forglemme Spreefloden og de mange kanaler, som faktisk gjorde byen til en ganske betydelig havneby. Der var mange grønne pladser og den store park Tiergarten og 


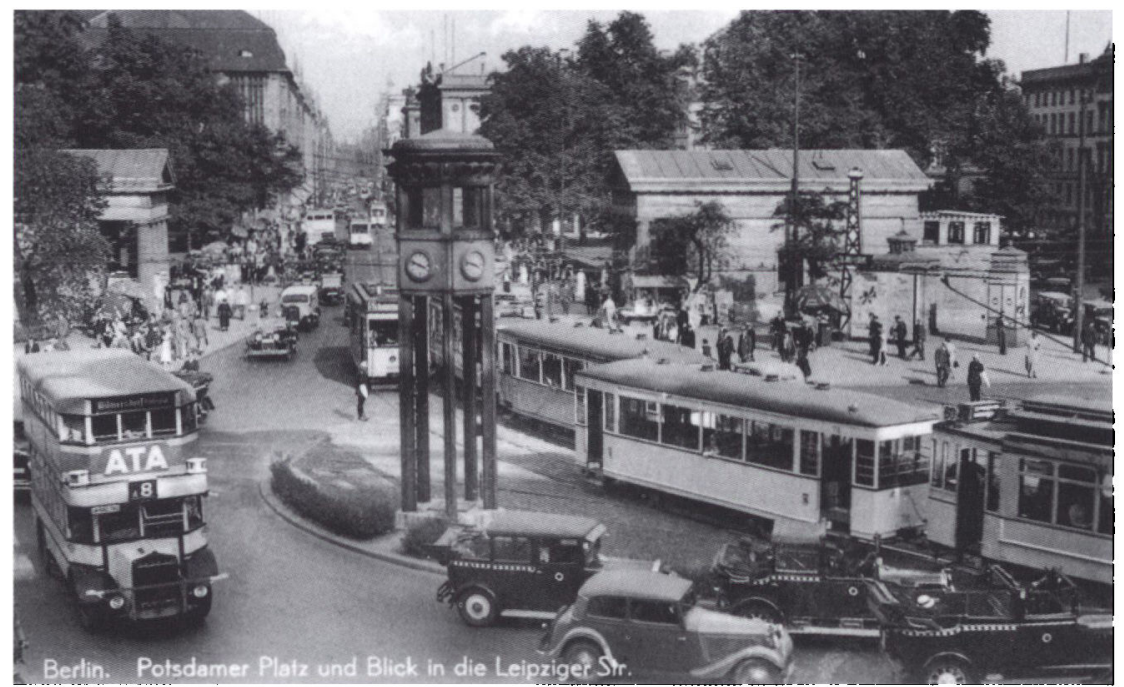

Berlin. Potsdamer Platz med et blik op ad Leipziger Strasse. Postkort ca. 1930.

mange anlæg, som gjorde, at millionbyen var til at leve i. Der var heller ikke langt til Havelfloden, til Grunewald og til hele den omegn, som var så helt anderledes end stenkolosserne $\mathrm{i}$ den indre by og de store arbejderkvarterer Kreuzberg og Wedding med deres triste lejekaserner, som lå langt fra den tilværelse, vi kendte ude fra det forstadsområde, hvor vi boede i SchönebergFriedenau.

Meget blev anderledes i efterkrigstiden. Den engang så livlige by var præget af grå tristhed, fattigdom og krigsinvalider. Dertil kom de politiske uroligheder begyndende med Spartakistoprøret i 1919, der kostede de venstreorienterede politikere Rosa Luxemburg og Karl Liebknecht livet. Endnu ser jeg for mig det sted ved Landwehrkanal, hvor deres lig senere blev fundet. Og jeg husker stedet, hvor den tyske udenrigsminister Walter Rathenau blev myrdet i 1921, fordi han søgte at komme til forståelse med vestmagterne. Hans mål var at lindre de økonomiske efterkrigsfølger, Tyskland døjede med, og som ikke mindst ramte den jævne befolkning.

Siden fulgte i marts 1920 Kapp-kuppet, da Generallandschaftsdirektor Kapp, en østprøjsisk kreditforeningsdirektør, gjorde sig til selvbestaltet rigskansler og tvang republikkens præsident og regering til skyndsomst at forlade hovedstaden. Selv om vi boede i den fredelige forstad Friedenau, mindes jeg hvordan panservogne drønede ned ad vort hovedstrøg Kaiserallé. Der blev skudt med gevær og maskingevær. En flink, dengang endnu pikkelhueklædt Schutzmann trængte os ind i sidegaderne. 
Med den tyske marks faldende værdi steg priserne, mens lønningerne var små, og for mange kneb det nu alvorligt at tjene tilstrækkeligt til mad og klæder. Her var vi til gengæld ret så privilegerede, idet vore slægtninge i Nordslesvig sørgede godt for os med levnedsmiddelpakker. Stor var skuffelsen, når sådan en pakke var landet $\mathrm{i}$ uvedkommende hænder og måske tømt for det meste af sit kostbare indhold. Der var jo stadig rationering også på brændsel, og det var noget nær en katastrofe, da tyve en nat havde hentet hele den netop ankomne forsyning af briketter. Kun fordi min far lå med en alvorlig influenza, kunne vi på lægeattest rekvirere nyt brændsel.

Værre blev det, da markinflationen for alvor satte ind i 1923. Pengenes værdi forringedes fra dag til dag, snart fik vi nye penge omtrent hver dag. Det begyndte med tusindmarksedler, snart blev det hundredtusinder, 1 million, 1 milliard for at slutte med 1 billion. En æske tændstikker kostede 900 millioner mark. Især for mange ældre, der havde sat deres lid til opsparede midler, blev det katastrofalt. Selv de gamle blå tusindmarksedler, der skulle være indløselige med guld, og som mange betragtede som nærmest noget i retning af et guldrandet værdipapir, blev totalt værdiløse. Modløsheden bredte sig, og ofte fulgte selvmord i katastrofens kølvand.

Da vi i oktober 1923 efter mors død af slægtninge i Hamburg var indbudt på besøg for at komme lidt til hægterne, fik far fra sit kontor i Berlin sendt penge hver dag. Men inden de nåede frem, var de kun det halve værd. I Hamburg var der iøvrigt også store demonstrationer og ofte vildt skyderi, så vi, der boede lige overfor rådhuset $\mathrm{i}$ Wandsbek, blev beordret til at holde os væk fra vinduerne. Da vi kom hjem til Berlin, var fars tyske penge i realiteten intet værd. Heldigvis havde vi dog nogle danske kroner, og det var jo en formue, som gjorde det muligt at leve videre. Men endnu ser jeg for mig, hvordan husmødrene stod parate ved deres mands arbejdsplads for at hente hans dagløn og få den omsat i varer, inden den nye Dollarkurs gav pengenes værdi et yderligere dyk og priserne et ryk opad.

Da den i Tinglev fødte rigsbankpræsident Hjalmar Schacht i slutningen af 1923 indførte Rentemarken - 1 billion blev lig 1 Rentemark - blev de indprentede kornneg straks opfattet som et varsel om bedre tider. Men uro var der stadig.

I 1922 kom jeg i skole. Da jeg samme år for første gang skulle på sommerferieophold hos slægtninge i Nordslesvig, blev jeg i skolen omgående hængt ud som dansker. Og det var ikke noget godt prædikat. Danmark hørte jo til de lande, der havde benyttet det tyske nederlag til landrov ved Nordslesvigs genforening. Denne hånlige danskerbetegnelse fulgte mig videre, da jeg både $\mathrm{i}$ 1924 og 25 igen skulle til Danmark. Og selv om jeg i 1926 skiftede skole og kom på gymnasiet, så var jeg stadig danskeren, der skulle kanøfles. Her må 
jeg med skam bekende, at jeg ikke klarede mig særlig stolt, når vor gymnastiklærer, en tidligere underofficer, beordrede en brydekamp i reglen med klassens stærkeste elev. Så var det ikke altid lige sjovt at være dansk.

Ellers var det da spændende at bo i Berlin. Vi tog meget omkring. Far holdt af de gamle bydele i Alt-Berlin, hvorfra byen fra et fiskerleje ved Spreefloden havde udviklet sig til en storby. Det blev til mange ture både i byen og omegnen, til Grunewald, Dahlem, Wannsee eller Werder. Det sidste sted kørte der endnu hestesporvogn helt til omkring 1920. Spændende var også besøg i Tøjhuset ved kejserslottet, hvor vi altid skulle finde de Dannebrogsfaner, prøjserne havde erobret ved Dybbøl, eller til Lichterfelde, hvor Istedløven stod i den tidligere Kadettenanstalt. Far havde allerede efter 1920 været ivrig for at få løven tilbage til Flensborg. 70 år efter er det stadig ikke sket. I slotskapellet $\mathrm{i}$ Charlottenburg hvilede de sidste tyske kejsere, Wilhelm I og Friederich III. Den sidste tyske kejserinde Auguste Viktoria, som var fra huset Augustenborg, var derimod bisat i Potsdam. Herude var det ellers især slottet Sanssouci med minderne om Friederich den Store, der var målet. Hans sarkofag stod i Garnisonskirken.

Gennem fars politiske engagement kom jeg med $i$ en drengeklub. Der var mange gode sammenkomster. Især havde jeg glæde af en rejse til Spreewald, dette mærkelige område nær Kottbus, hvor Spreefloden delte sig i flere arme. Naturen derude var dejlig. Her boede venderne - nu kaldet sorberne - med deres eget for os helt uforståelige sprog og en speciel byggestil. Typiske er de mange gangbroer over flodarmene. Ellers gik vore sommerferierejser i reglen til Aalbek ved Swinemünde med de mægtige strandområder.

Politisk var Berlin ligesom hele Tyskland i disse år præget af stadig uro. Endnu står klart for mig hin kolde dag i begyndelsen af marts 1924, da rigspræsident Friedrich Eberts kiste fra Rigsdagsbygningen blev båret ud til rustvognen. Der var nok nogle blandt de tusinder, der her i Lustgarten fulgte Eberts sidste færd, som tænkte: mon ikke det er Weimarrepublikken, der bæres til graven. Eberts efterfølger blev den gamle feltmarskal Paul v. Hindenburg. Jeg nåede at opleve ham en enkelt gang, da han stiv og ubevægelig sammen med rigskansler Marx kørte ad Unter den Linden til Rigsdagsbygningen.

Mange så $\mathrm{i}$ ham en mellemstation på vejen til kejserdømmets genoprettelse. Måske ikke lige Wilhelm II., der under navnet Lehmann i 1918 var flygtet til Holland og nu fordrev tiden med at kløve brænde. Men hans søn kronprins Friedrich Wilhelm havde mange tilhængere. Selv oplevede jeg, hvordan han blev hyldet nærmest fyrsteligt af ret så mange tilskuere, da han ankom til en flyveopvisning i Tempelhof. Som tiden gik, eskalerede den politiske uro. Ikke mindst forud for de evigt tilbagevendende valg. Kæmpedemonstrationer, slagsmålog skyderi hørte efterhånden til dagens orden. Far fulgte spillet på nærme- 
ste hold og sendte adskillige artikler om disse forhold til danske aviser. Som overbevist socialdemokrat fulgte han partiet og Reichsbanner, den mere kampberedte del af partiet, som også stod for de store demonstrationer. Her hændte det tit, at Reichsbanner, kommunisternes Rote Frontkämpfer-kamporganisation og nazisternes SA demonstrerede samtidigt. Selv om politiet søgte at holde dem på afstand fra hinanden, skulle de nok finde sammen til kæmpeslagsmål, der mere end én gang krævede menneskeliv. Så arrangeredes der kæmpebegravelser, som igen mødtes med moddemonstrationer. Gadekampene varslede ilde for den $\mathrm{i}$ forvejen svage Weimarrepublik.

For os danske var der til gengæld altid en oase i den danske forening Freja, hvor jeg første gang så et med Dannebrog pyntet juletræ. Jeg oplevede også en fin fortolkning af nogle af $\mathrm{H}$. C. Andersens eventyr ved professor Vilhelm Andersen. Og der blev sunget danske julesange, som jeg ganske vist med mit endnu tyske sprog ikke forstod ret meget af. Freja var stedet, hvor især de voksne kunne udveksle minder hjemmefra. Den danske præst pastor Hedegaard fik vi ofte besøg af. Han var en trofast hyrde for sin danske hjord $i$ byen.

I Berlin boede en gammel dame, fru Hansen, der var fra Haderslev, født i huset i Badstuegade med de to fine karnapper. Hende besøgte vi ofte, for her kunne man jo snakke dansk. Hun nåede at blive 103 år gammel. På sin 100årsdag fik hun et telegram fra Hitler. Hvordan den gamle dame reagerede, ved jeg ikke. Selv var hun dansk, men hendes børn var gået den tyske vej.

Som næunt var jeg om sommeren i årene 1922, 1924 og 1925 på sommerferie i Danmark. Det var som at komme i paradis, for i Danmark boede efter god gammel sønderjysk opfattelse kun ordentlige mennesker, og selvfølgelig skinnede solen hele sommeren. Alligevel blev min første rejse noget forstyrret. Vi havde i Berlin haft besøg af slægtninge fra Nordslesvig. De danske penge stod allerede i 1922 højt i kurs, så en Berlinrejse kostede ikke mange kroner. Disse slægtninge ville nu have mig med på en ferietur, der samtidig skulle være en fedekur, og det kunne vel nok være nødvendigt. Glad rejste vi af sted og var nået til den gamle grænsestation ved Harreslev, da min onkel opdagede, at han undervejs - formentlig under et ophold i Hamburg - var blevet frastjålet sin tegnebog sammen med vore pas. Der stod vi altså lige udenfor paradisets dør og kunne endda se ind i det forjættede land, men uden pas var døren lukket. Min onkel kunne ganske vist få et pas på det danske konsulat i Flensborg, men for mig var der ingen hjælp at hente. Vi måtte skyndsomst rejse tilbage til Berlin, for at jeg kunne få nye papirer. Så gik turen nordpå igen. Når jeg i dag fra toget ser den efterhånden noget derangerede tidligere grænsestation, kan jeg aldrig lade være med at tænke på hin for en 6-årig så dramatiske oplevelse. 


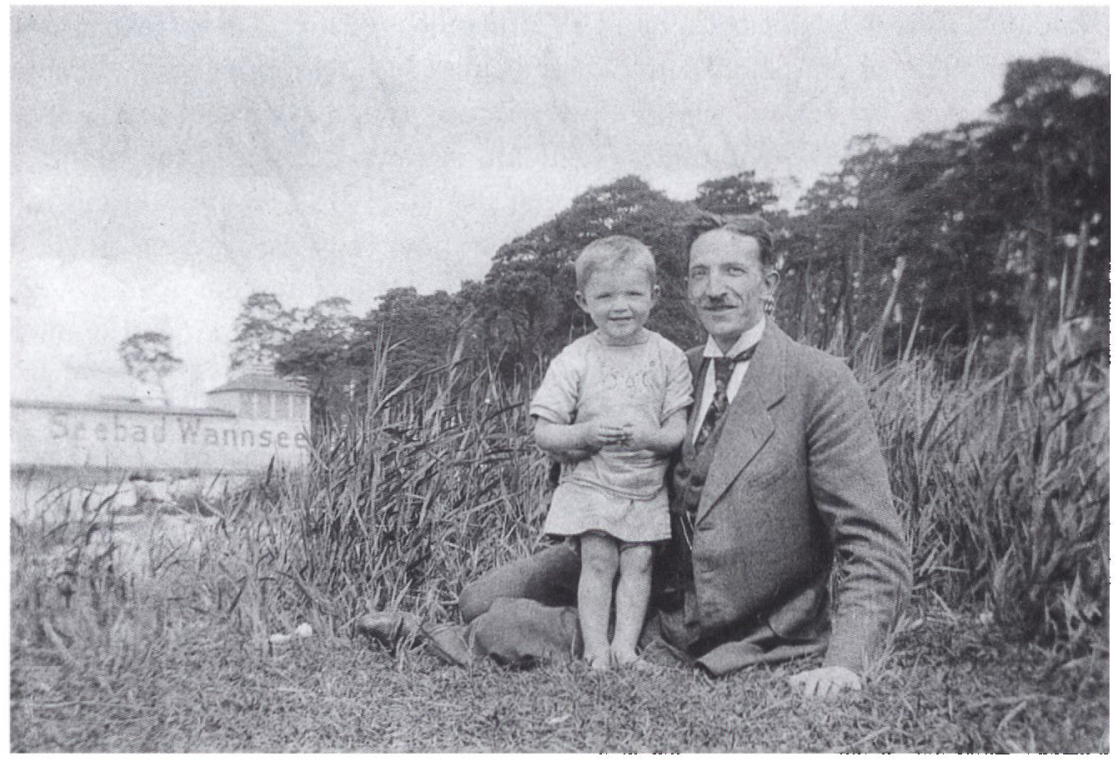

Far og jeg ved Seebad Wannsee. Foto 1919 i privateje.

Mit første ophold i Danmark blev i Årøsund ved Lillebælt. Jeg havde fået forlænget sommerferie, og den varede virkelig længe, men alligevel lærte jeg ikke at tale dansk. Det var jo kun to år efter Genforeningen, og alle kunne tysk, så hvorfor snakke dansk med Berlinerdrengen?

Fra dette ophold husker jeg fynboernes besøg i Øsby sogn. De kom sejlende med færgen fra Assens og blev standsmæssigt afhentet med fine hestekøretøjer for siden at blive indkvarteret hos deres respektive værtsfolk. Der var endnu dengang en meget levende kontakt hen over Lillebælt mellem fynboer og sønderjyder.

Jeg kom til Danmark igen i 1924, dengang til Hajstrup, hvor vi også havde en del slægtninge. Dér lærte jeg omsider at snakke dansk eller sønderjysk, endda så meget, at jeg ved hjemkomsten næsten havde glemt mit tysk. Det kom dog meget hurtigt igen. En ting blev dog hængende, nemlig at sige »tak for mad « på dansk. Det tør nok siges at være ganske værdifuldt. Under ferieopholdet i Hajstrup oplevede jeg indvielsen af den genforeningsten, som stadig findes i landsbyen. Det var min fars farbroder, Mathias Rudbeck - tidl. ejer af Hajstrupgård og nu pensionist eller rentier $\mathrm{i}$ landsbyen - som skænkede denne sten. Stenen var fundet på Hajstrupgårds marker. Nu fik den indskriften: "Ja mange trange Aar der gik/ men trængslen sin løsning fik/ Hav Tak, oh Gud, fordi Du førte/os hjem til Danmark hvortil vi hørte«. Som 
påskønnelse for sin indsats fik han i 1926 Dannebrogsmændenes Hæderstegn.

Også i 1925 var jeg på ferieophold, dengang i Jels. I forbindelse med denne rejse kom vi en hel del omkring. Far var med, og vi besøgte slægtninge i Århus og Odense. Det blev iøvrigt under denne tur, jeg første gang kom på vandring i Dybbøl skanser og gik en tur over den gamle, længst glemte pontonbro i Sønderborg. Man betalte 5 eller 10 øre for at passere broen.

I marts 1927 var min Berlinertilværelse for alvor slut. Slut med skolen, Rheingau-Schule, en tysk Oberrealschule. Skolen har overlevet krigens bomberegn. Jeg kunne godt have undt den en mindre heldig skæbne.

\section{Haderslev}

Fra 1927 skulle jeg til at være dansker. Det var unægtelig noget af en forandring at komme fra storbyen Berlin til den beskedne købstad Haderslev. Slægtninge havde skaffet os en lejlighed i Sønderotting hos en fjern slægtning. Jeg skulle desuden i dansk skole og blev tilmeldt fru Signe Tørslevs private realskole i Laurids Skausgade. Det var en stor overgang pludseligt i hverdagen helt at være omgivet af det danske. Signe Tørslev var en særdeles velagtet pædagog. Hendes datter, senere minister Lis Groes, gik et par klasser over mig. Jeg husker hende som en stor glad pige. Der var ingen tvivl om, at jeg var kommet $i$ en god skole med dygtige lærere og en ånd, der var væsentlig forskellig fra den, jeg hidtil havde mødt $\mathrm{i}$ den tyske skole.

Mit danske sprog, dvs. sønderjysk dialekt, var jo ikke særlig fremragende. Jeg var dog heldig som klasselærer at få en meget dygtig lærer i Andreas Gjede - i øvrigt en barndomsven af min far fra hans tid på Sønderbro. Lærer Gjede forstod hurtigt at bringe mig over mine sproglige mangler. Men endnu ser jeg for mig de mange røde streger i den første danske diktat. Det blev dog forbavsende hurtigt bedre, så jeg snart kom til at beherske også det rigsdanske sprog.

Dog i skolen blev jeg opfattet som tysker. Det fik jeg tit nok at vide af mine kammerater. De syntes, det var besynderligt, at jeg under et optog på Valdemarsdagen den 15. juni fik lov at bære et lille Dannebrog. "Se ham tyskeren«, lød det. Det var egentlig ikke spor morsomt, når man nu så længe i Berlin var blevet hængt ud som dansker.

Der skete mange spændende ting, bl.a. de dengang årlige kongebesøg. Endnu ser jeg den gamle hjuldamper "Dannebrog « snegle sig ind gennem fjorden. Tænk her kom altså en rigtig konge. Eller indvielsen af mindesmærket i Damparken over de faldne i 1 . Verdenskrig, hvilket skete med fuld militær honnør. Eller at se 18. bataljon med musik i spidsen marchere ud til det gamle øvelsesområde på Starup Hede. 
Min far nød at færdes i sin barndoms by. Der var også omegnen, Erlev, Hørregård, §5 - et nu nedlagt traktørsted for enden af Haderslev dam - og der var skovene. Med »E Lillebahn«, amtsbanen, kunne vi komme vidt omkring, både ud på Haderslev Næs for at besøge familien, til Christiansfeld og især til Vedsted, idet min far var begyndt at efterforske vor slægts rødder. I Vedsted sad pastor N. P. Nielsen, senere grænsepræst i Højer. Det blev til adskillige besøg i den dejlige præstegård ved Vedsted sø, hvor jeg kom på roture med præstens sønner, mens far studerede gamle kirkebøger.

Vel var Haderslev en overvejende dansk by, men der fandtes også hjemmetyskere, ikke mindst blandt forretningsfolkene. Der var så vidt jeg husker kun én dansk slagter $\mathrm{i}$ byen, resten var tyske. På Lindevej, hvor vi boede, havde tobaksfabrikant Mathias Hansen sin villa. Endnu kan jeg se hans ranke skikkelse. Han holdt sig også rank, da nazisterne maste frem. Det var ikke hans folk. Han hørte til den lille kreds, der senere i 1943 under navn af Haderslevkredsen fostrede ideen til den loyalitetserklæring, det tyske mindretal afgav $i$ 1945.

Nok havde jeg nu lært dansk $i$ alle sprogets variationer. Men at f.eks. ordet sgu var et for mange rædsomt ord, anede jeg intet om. Vor brave gamle husvært brugte det tit og ofte, og det lød i mine drengeøren ganske flot. Stor var min forundring, da en flink ældre dame af vort bekendtskab en dag stak mig en hel papirs 1 krone, hvis jeg lod være med at bruge det skrækkelige ord.

\section{Aarøsund}

Vi blev kun i Haderslev knapt et år, så flyttede vi til Årøsund, hvor en anden slægtning kunne skaffe os en nyopført villa til leje. Den var imidlertid ikke helt klar, så først boede vi en tid på Årøsund Badehotel. Her kom vi til at opleve den hårde vinter 1929, da hele Lillebælt frøs til. Man kunne gå, ja vist endda køre helt til Assens. Den lille ø Årø var blevet landfast.

Denne flytning betød, at jeg igen måtte skifte skole. Nu blev det landsbyskolen i Hajstrup med en ældre missionsk førstelærer Iver Schmidt og en yngre andenlærer P. F. Gotthelf, som ganske vist var radikal, men samtidig var yderst optaget af historie. Det er ofte sagt, at disse landsbyskoler stod og faldt med lærerne. Hos den gamle førstelærer lærte vi religion. Søndagsevangeliet og de dertil hørende salmer skulle vi helst kunne udenad om lørdagen. Han var af den gamle skole, havde vist før 1920 haft lidt tyske sympatier, men kunne forlade skolen som en velestimeret dansk lærer.

Da lærer Gotthelf blev førstelærer, kom der straks en helt anden melodi på. Hvad vi dog lærte! Aldrig har jeg hørt Danmarkshistorie, verdenshistorie eller 


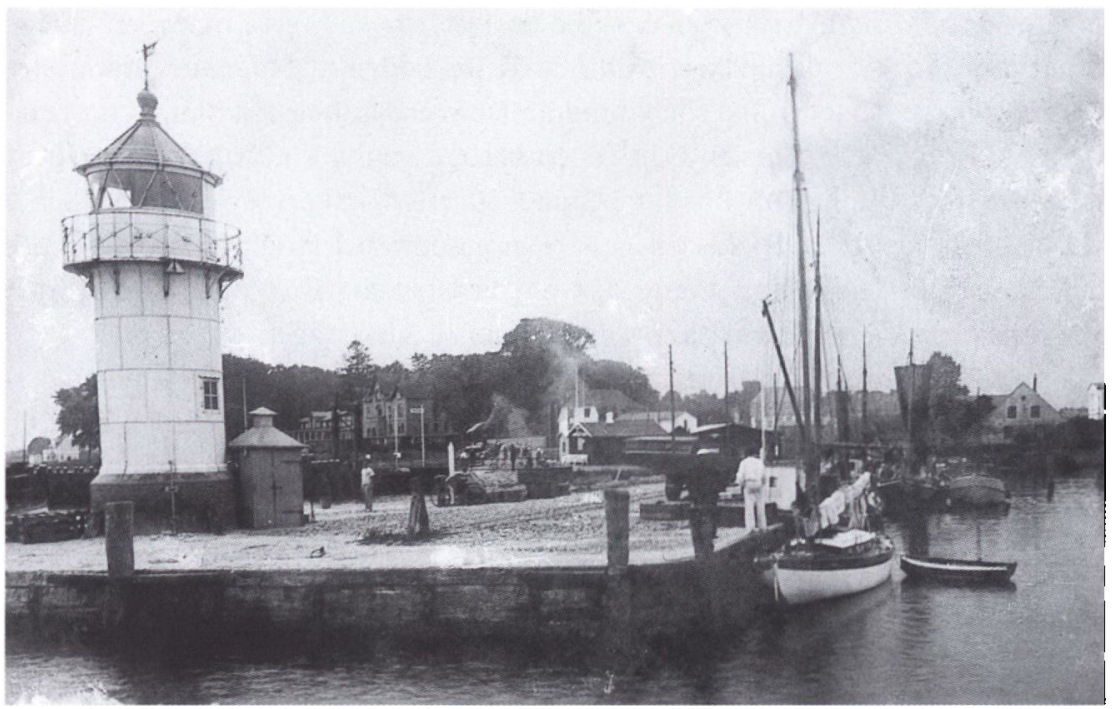

Aarosund i $1930^{\prime}$ erne. Foto i Haderslev byhistoriske Arkiv, Sv. Ohlsens samling.

geografi fortalt mere levende. Også den danske litteratur fik vi et indblik i, samtidig med at de øvrige vigtige fag ikke blev forsømt. Vi lærte lige så meget i de sidste halvandet år, som vi nok normalt skulle bruge hele skoletiden til. Da jeg hurtigt viste interesse for læsning, fik jeg lov til at låne en mængde gode bøger. Lærer Gotthelf vidste nok, hvad man burde læse. Havde han ikke bøgerne i sit eget sognebibliotek, så blev de skaffet fra centralbiblioteket i Haderslev. Det blev siden hen en god ballast for mig, som jeg kunne arbejde videre med. Men helt almindeligt er det nok ikke at gå fra gymnasium til realskole for så at slutte $i$ en landsbyskole.

Da vi nu boede i Øsby sogn, hvor min slægt havde levet og virket i et par hundrede år, var det for min far helt naturligt at beskæftige sig med såvel slægtens som sognets historie. Der viste sig en del interesse blandt beboerne, og der nedsattes et lokalhistorisk udvalg. Museumsdirektør Chr. Lund, Haderslev, fulgte arbejdet med stor opmærksomhed og holdt desuden en række lokalhistoriske lysbilledforedrag. Og han selv blev en hyppig gast hos os. Det blev til en række ekskursioner med besøg i gamle gårde og huse og med at studere gravhøje, mark- og andre stednavne. I sognet lå den store Tamdruphøj, en af landsdelens største gravhøje og vidt synlig helt ude fra Lillebælt. Også andre egne især i Haderslev amt kunne Chr. Lund fortælle om og gøre levende for os gennem sine billeder. Det blev faktisk en ganske god hjemstavnsskoling, som jeg fik lejlighed til at følge. Det var nærmest blevet en 
fortsættelse af den Heimatkunde, vi i den tyske skole startede geografiundervisningen med, og hvor vi simpelthen startede i vor egen forstad, Friedenau, for så over Berlin at arbejde os videre ud i Mark Brandenburg. Længere nåede vi faktisk ikke i mine første - tyske - skoleår. I Hajstrup skole blev geografi hurtigt et vigtigt fag.

Som fjortenårig blev jeg konfirmeret af pastor F. Smith i Øsby kirke, og dermed ophørte også for mig skolen i denne omgang. Vel anbefalede min lærer, at jeg skulle læse videre; det tillod fars ret beskedne pension imidlertid ikke, og desuden var der jo den daglige transport. Trods alt havde vi $15 \mathrm{~km}$ til Haderslev. I stedet skulle der findes på noget andet. Både far og lærerne havde hele tiden sørget for, at jeg læste meget og desuden fik lov til at boltre mig med at skrive stile om mange mærkværdige ting. Det mente han nemlig, at jeg var særdeles god til. Ikke mindst mine stile var årsag til, at de begge skønnede, at jeg kunne blive journalist. Men dels var jeg lovlig ung, dels havde man på Dannevirke i Haderslev ikke brug for en elev, så tanken blev, at jeg skulle læse videre derhjemme. Det var jeg nu ikke særlig interesseret i. Kunne jeg ikke blive journalist, måtte jeg finde på noget andet, og når man boede på landet, var det nærmeste jo at vælge landmandsgerningen. Man kunne jo altid blive landmand - hed det dengang. Så jeg valgte at blive landmand.

\section{Læreplads i landbruget}

I maj måned 1930 startede min landmandskarriere hos den på egnen ret kendte gårdejer Simeon Sørensen i Hajstrup. Han var fra Koldingegnen og var efter Genforeningen flyttet til Sønderjylland, hvor hans kone stammede fra. Den gård han købte, skulle gøres til noget af et mønsterbrug, men her skrævede han længere, end bukserne kunne holde. Økonomisk kneb det meget, ikke mindst da landbrugskrisen for alvor satte ind. Alligevel drev han et efter datidens forhold ret moderne landbrug. Samtidig var han yderst alsidigt orienteret som højskolemand og andelsmand. Politisk fulgte han Retsforbundet, hvor han ved adskillige valg var partiets folketingskandidat. Det var således mange forskellige emner, der blev talt om i dette hjem, og jeg var altid en yderst videbegærlig tilhører. Jeg fik lov til at bestille noget, og tilegnede mig samtidig en begyndende viden ikke kun om landbrug, men også om det folkelige arbejde.

Efter et års forløb valgte jeg at søge plads hos en mere jævn landmand $\mathrm{i}$ Hyrup, gdr. Thomas Kjær, hvor jeg lærte ikke så lidt af den praksis, det også var nødvendigt at være hjemme i. Dengang krævedes på alle områder en større fysisk indsats end i dag. Landmandsgerningen var noget aldeles nyt og ukendt 
for mig. Det blev lærerige år, og mange praktiske ting fik jeg lært både af de ældre medhjælpere og de daglejere, der hjalp til ved særlige lejligheder som i høsten, ved gødningskørslen eller i skoven. Jeg kom også til at hjælpe, da der skulle lægges nyt tag på en længe, vel at mærke stråtag. Jeg lærte at omgås kreaturerne og hestene.

Det var praktisk at kunne slå med le. Dengang høstedes der endnu for $\mathrm{i}$ kornmarken, inden selvbinderen forspændt tre heste begyndte kornmejningen. At læsse en høstvogn rigtigt var slet ikke så lige til. Det krævede øvelse, ville man undgå at hele læsset røg af, når man kom ud på de ujævne grusveje. Det krævede gode kræfter, når høet skulle forkes op gennem en altid alt for snæver lem over kostalden, eller når kornnegene skulle læsses af $i$ laden. Det skulle altid gå stærkt, så næste læs ikke skulle vente. Læsning af gødning og gødningsspredning krævede også gode kræfter. Og der skulle hakkes roer, hvor man til gengæld skulle passe på, at der kun blev een plante - og kun een plante - tilbage.

Om vinteren var der i reglen snekastning. Sneplove kom først efterhånden $\mathrm{i}$ brug, og fandtes de, kom de sjældent ud på de mindre veje. Havde sneen efter en fygning lagt et meterhøjt lag mellem de høje hække, så var det ud med skovlen. Det kunne være ganske fornøjeligt, når vi unge fra alle gårde mødtes til snerydning.

Også dengang kendte man til genbrug. Bindegarnet fra kornnegene blev under tærskningen samlet op. Om vinteren kunne vi fornøje os med at samle båndene til lange snore, som med en særlig indretning blev snoet til reb, enten tømmer eller hammelreb. Og endelig var der jo hestene, der skulle passes godt. Det var kun ganske enkelte større gårde, der havde en traktor.

På gården i Hyrup var vi to karle og en fodermester, og i huset var der en ung pige. Det var nok det mest almindelige folkehold på gårde op til en 50-70 ha. Kobesætningen af korthornsrace var en 18-20 stk. foruden ungkvæg og en del stude. Meget blev drevet på ret gammeldags vis. Overgangen fra det landbrug, man drev i tysk tid til mere moderne dansk landbrug tog sin tid.

I landsbyerne var der således en talrig ungdom, som efter den lange arbejdsdag mødtes, hvor lejlighed fandtes. Lønnen opfordrede ikke til de helt store udskejelser. En forkarl fik fra 600-800 kr., de andre karle fra 300 til $500 \mathrm{kr}$. om året. Udgifterne var ganske vist heller ikke høje. En 10-styks pakke cigaretter kostede 35 øre, en pakke tobak 50 øre. Et par gummistøvler kostede $15 \mathrm{kr}$. og et pænt sæt tøj kunne erhverves for mindre end $100 \mathrm{kr}$. Men landbrugets indtjening var også beskeden. Landbrugskrisen var begyndt, og først i midten af 30'erne bedredes forholdene.

Priserne var små, $7 \mathrm{kr}$. for en tønde byg, $30 \mathrm{kr}$. for en gris til slagteriet og $100 \mathrm{kr}$. for en velvoksen stud. Det gav ikke mange penge til landmændene. 


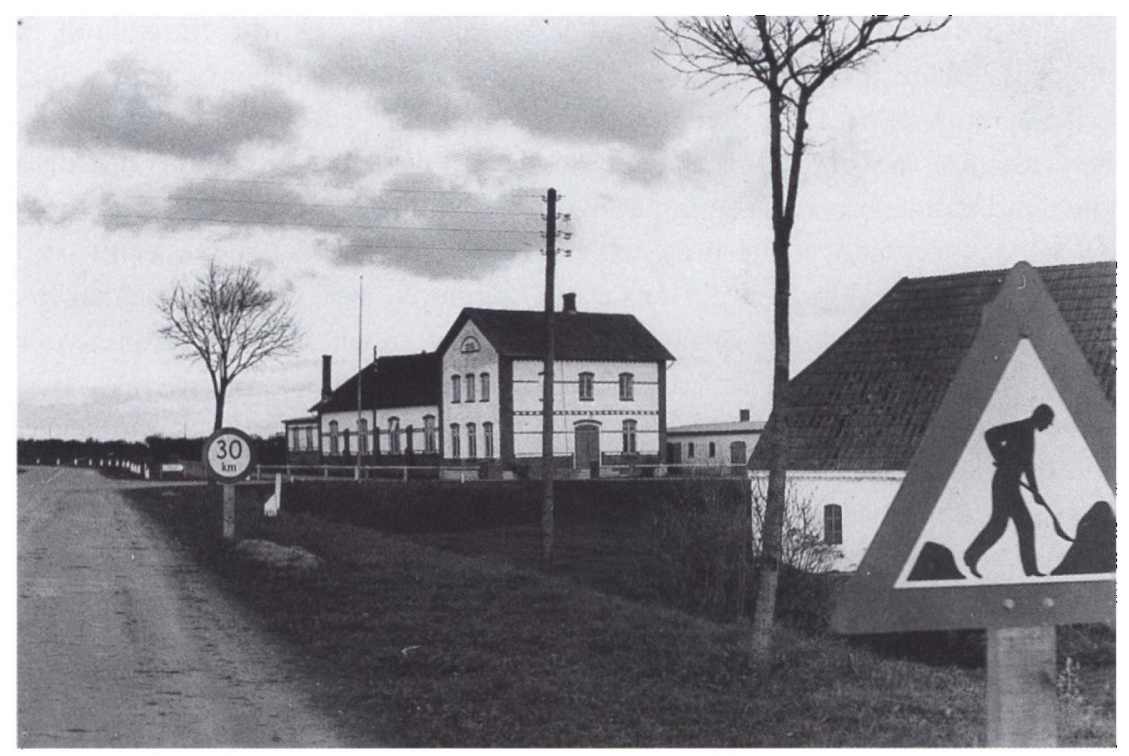

Hyrup forsamlingshus. Foto i Haderslev byhistoriske Arkiv.

Arbejdsløsheden var en anden frygtelig svøbe, som på landet tvang mange ellers gode arbejdere til at slå skærver for kommunen. Det blev kun til det daglige brød, og skulle man nøjes med den sparsomme understøttelse, kunne det nemt se sort ud.

Vi savnede ikke forsamlingssteder. I Hyrup lå forsamlingshuset for Haderslev Næs. Her blev jeg i de følgende år en hyppig gæst. Det var en selvfølge at deltage i afstemningsfester, genforeningsfester og festen på kong Christian X.'s fødselsdag. At jeg også så småt begyndte at interessere mig for det politiske liv, mindes jeg ved, at jeg forud for folketingsvalget 1932 overværede et vælgermøde, hvor greve Bent Holstein talte. Han havde tidligere været konservativ og var nu løsgænger og skulle til at reformere Venstre. Han blev så vidt jeg husker opstillet i Løgumklosterkredsen. I 1932 var han det sønderjyske Venstres trækplaster. Han forstod at belægge sine ord overfor de kriseramte sønderjyske bønder.

I efteråret 1932 flyttede min far til Flensborg, men jeg havde jo truffet mit valg. Som de politiske forhold tegnede sig i Tyskland, havde det ikke just min interesse at flytte med derned. Jeg havde besluttet mig til at søge dansk statsborgerskab. Desuden havde jeg fået så meget smag for landbruget, at jeg håbede på at finde en fremtid indenfor dette erhverv.

Den 1. november 1932 fik jeg plads hos en anden meget anerkendt land- 
mand, gårdejer Jens Brask i Flovt. De tre år på Skovgård i Flovt kom til at betyde uhyre meget for mig. Jens Brask, der oprindelig havde været mejeribestyrer i Nørre Bjert ved Kolding, havde i 1919 købt Skovgård, og ligeså dygtig, som han efter sigende havde været som mejerimand, blev han som landmand. Hans besætning af rødt dansk malkekvæg hørte til de bedste, og det var mange fine præmier, han hentede hjem fra dyrskuerne. Måske var han ikke lige den der snakkede så meget med os unge mennesker, men var der noget, man gerne ville vide noget om, kunne man altid være sikker på at få en god belæring.

Det var dog ikke kun landbrug, jeg lærte hos Jens Brask. Det folkelige, politiske og nationale arbejde lå ham stærkt på sinde. Når der var møde $\mathrm{i}$ forsamlingshuset eller i Haderslev spurgte han altid, om nogen ville med. Og det var jeg praktisk talt altid rede til. Derved kom jeg til at høre en mængde foredrag af den tids kendte folkelige talere, Hans Lund, Rødding, Sune Andresen, Engelsholm, Claus Eskildsen, H. P. Hanssen, C. P. O. Christiansen, Frederiksborg, Damgård, Ryslinge, Arnfred fra Askov og derfra desuden Juhl Andersen, Jørgen Bukdahl og Hans Haarder foruden også Dansk Samling eller Det tredie standpunkts profet Arne Sørensen. Der var fremragende oplæsningsaftener med lærerparret Demuth fra Ravsted og af pastor Rydahl, der netop var kommet til Halk og viste meget stor forstålse for det folkelige arbejdes betydning netop i Sønderjylland. Det var forsamlingshusliv, når det er bedst. Selvfølgelig hørte vi også betydende landbrugstalere, Hans Hansen og J. Lauridsen, Graasten, Overgaard, Ladelund, og Møller, Hammerum, for ikke at forglemme vor egen dygtige konsulent Fr. Nielsen.

Også politisk fulgte vi med. Til vore nærmeste naboer hørte gårdejer Einar Simonsen, Flovtgård, der havde været folketingskandidat for Venstre på Mors i 1932 og nu opstillede i Bækkekredsen, hvor han blev valgt i 1935. Vore to gårde arbejdede meget sammen, og de to mænd fulgtes meget ad, så der blev tit lejlighed for at smutte med til et politisk møde.

Omkring 1935 oprettedes en VU-forening i Haderslev, som jeg blev medlem af. Ved den lejlighed hørte jeg første gang den senere statsminister Erik Eriksen. Han var en god ven af Einar Simonsen, så det var også helt naturligt, at Erik Eriksen blev hentet til et møde i Øsby, hvor de konservative mødte med redaktør Asger Carstensen og redaktør Adolf Svensson. Med den sidste tørnede Erik Eriksen voldsomt sammen, da Svensson stillede sig tvivlende overfor Venstres nationale interesser, når Venstre efter hans skøn ville sikre sig aflad ved at skænke et klaver til et forsamlingshus i grænseegnen. Det ville Erik Eriksen ikke lade gå upåtalt hen, og det blev til et voldsomt opgør, endda så voldsomt, at Svensson ikke ville sige farvel til ham. Siden tog Erik Eriksen 
hævn. Da Svensson blev valgt ind i Rigsdagen og ville hilse på Erik Eriksen, afviste denne ham med bemærkningen om, at en mand, der ikke kunne sige farvel, ville han heller ikke sige goddag til.

Ellers var det politiske liv stærkt præget af de voksende modsætninger mellem Venstre og LS. Einar Simonsen havde kun meget lidt til overs for LS-folkene. Hans jomfrutale i Folketinget var et kraftigt opgør med Det frie Folkepartis, senere Bondepartiets ledende skikkelse, Valdemar Thomsen, et sammenstød, der dengang blev lagt stærkt mærke til. Der blev dog også lejlighed til at høre andre politiske talere som den stoute vendelbo Jens Sørensen Vanggaard, den konservative leder Christmas Møller, Venstres høvding Madsen Mygdal, Knud Kristensen og de sønderjyske politikere Hans Jefsen Christensen, Erik Appel og Simon From. Måske man her vil indvende, at det jo var ene borgerlige, men det siger samtidig lidt om, hvor mine interesser allerede dengang lå. Når det blev lidt ensidigt skyldes det måske også, at flerkantede politiske møder faktisk ikke var særlig på mode i Sønderjylland.

Men jeg hørte også politikere, jeg ikke var nær så optaget af. En aften var jeg således til et møde, hvor Danmarks daværende nazifører ritmester Lembcke ville overbevise os om sin udgave af en dansk nazisme. Den aften var der nærmest øretæver i luften, da jeg på hjemvejen absolut måtte modsige Lembckes nazistiske visioner. Lige så lidt kunne jeg sympatisere med pastor Anders Malling, Brøns, da han ville præsentere et Nationalt Samlingsparti, hvis signaler også tydeligt var påvirket af det nye ordenssystem sydpå.

En af mine meget nære venner var Peter Lindberg fra en gård i Brabæk oppe ved den gamle grænse. Vi lærte hinanden at kende, mens han et års tid havde plads i Hyrup. Allerede dengang færdedes vi meget sammen, og helt til krigsslutningen besøgte jeg ham jævnligt $\mathrm{i}$ hans hjem. Det var herlige dage, hvor vi cyklede langs den gamle grænse over Kjær Mølle og Tårning til Christiansfeld eller rundt om noret til Hejls og Hejlsminde.

Ellers var livet på landet anderledes stilfærdigt end nu om stunder. Bilen var endnu ikke hvermands eje. I Hyrup fandtes kun én bil, den lokale købmands lastbil. I Flovt havde Chr. Gunge på Vestergård en bil, og Einar Simonsen og Jens Brask var fælles om en bil. Ellers var det jo hestekøretøjerne, der sås på vejene. De offentlige transportmidler var $\# Æ$ Lillebahn« mellem Haderslev og Årøsund med stationer i Øsby, Hyrup, Hajstrup og Råde. Folk i Flovt, der ikke ejede eget køretøj, måtte tage enten til stationerne i Øsby eller Hajstrup. Rutebilen fulgte også kun den slagne hovedvej til Haderslev. Udlængslen var knap så stor som $\mathrm{i}$ vore dage. Man tog sjældent længere bort, i reglen kun $\mathrm{i}$ den nærmeste omegn, og ellers blev man hjemme. Også her er tiden da heldigvis - blevet en anden. 


\section{Danske foreninger - Det unge Grænseværn}

Som allerede nævnt så min far sig i efteråret 1932 tvunget til at flytte til Flensborg, hvor han meget hurtigt kom til at deltage i det danske mindretalsarbejde. De politiske skyer var imidlertid mørke. Den 30. januar 1933 overtog Hitler magten, og mange håbede, at han ville rette Tyskland op igen og frigøre det for den skændsel, man havde levet under i Weimarrepublikken. For folk af en anden mening gjaldt det om at gå stille med dørene.

Af breve, jeg fik fra far, kunne jeg tydeligt se, at han blev forsigtig med, hvad han skrev, ligesom han advarede mig mod i breve at udtrykke mine politiske meninger alt for tydeligt. Censuren var jo indført, og desuden hørte jeg allerede under mit første besøg i Flensborg efter magtskiftet om denne og hin, der var blevet afhentet og som siden var meget stilfærdige. De var blevet omskolet. De første koncentrationslejre kaldtes da også Schulungslager, steder hvor de vrangvilligt indstillede blev skolet $\mathrm{i}$ den rette ånd.

Det sås også på fars artikler. Hvor han tidligere ofte ret kritisk havde skrevet om de politiske forhold $\mathrm{i}$ Tyskland, måtte han nu skifte til mere neutrale emner som egns- og slægtshistorie eller muntre historier, nogle $\mathrm{i}$ sønderjysk dialekt.

I et så dansk hjem, som det jeg var kommet til på Skovgård i Flovt, var det en selvfølge at deltage $i$ de nationale fester i forsamlingshuset. Vor gamle sognefoged Martin Simonsen, som i 1918-20 havde været sekretær for Den nordslesvigske Vælgerforening og en af H.P. Hanssens nære medarbejdere, hørte til vore naboer. Far havde mange samtaler med denne stoute sønderjyde, og det var ikke uden betydning for mig. Under de nationale møder tog Martin Simonsen ofte ordet og opfordrede til sønderjysk sammenhold, da ingen kunne vide, hvilke prøvelser landsdelen ville blive udsat for.

I 1933 fulgte de store nationale stævner. Tønderstævnet i maj 1933 arrangeret af sønderjysk idrætsungdom var vi vist ikke rigtig opmærksomme på. Vi kom i hvert fald ikke derned. Derimod skulle vi alle til Dybbøl den 11. juni. Imidlertid fik jeg en influenza og måtte blive hjemme og nøjes med $\mathrm{i}$ radioen at høre den del af stævnet, der blev transmitteret. Men de stærke ord, der ikke mindst lød fra nogle unge sønderjyder, gjorde unægtelig et stort indtryk.

Lokalt var det Haderslev Næs Ungdoms- og Foredragsforening, der samlede os, og det var ikke den ringeste skole. Vel blev der også lagt vægt på gymnastik og folkedans, men de folkelige og nationale foredrag havde en høj prioritet. Formand for foreningen var i disse år gdr. Jens Jensen, Sode, en meget alsidig orienteret bonde. Endnu var det jo i høj grad den ældre generation, genforeningsgenerationen, der prægede disse møder, og som ofte tog ordet. Foruden Martin Simonsen var det sognets første sognerådsformand efter Genforenin- 
gen, amtsrådsmedlem Hans Kjær, den meget lyrisk anlagte gdr. Erik Eriksen, Halk, og ofte også Einar Simonsen.

I 1932 blev der oprettet et sangkor, som jeg havde megen glæde af at være med i, og der oprettedes en studiekreds. Og så blev der sunget, de fleste danske sange, jeg stadig kan, lærte jeg i disse år.

Den 26. september 1933 fejredes som sadvanligt kongens fødselsdag. Taler ved den lejlighed var en mig ganske ukendt seminarielærer Peter Marcussen fra Haderslev. Det blev en meget mærkelig tale. Han kom lige fra et møde i Aabenraa, og at der lå noget i luften, var tydeligt, men hvad det egentlig drejede sig om, fik vi ikke rigtig rede på, kun at der snart kunne ventes et dansk nationalt udspil overfor de voldsomme tyske udfordringer, som kom fra grænseflytningsgale slesvigholstenere som borgmester Wilhelm Sievers, Egernførde, og pastor Johann Peperkorn fra Fjolde.

Få dage efter kom budskabet om oprettelse af Det unge Grænseværn. Her var det helt naturligt at melde sig, og året efter deltog jeg i det store stævne på Skamling, hvor ca. $\mathbf{4 0 . 0 0 0 ~ m e n n e s k e r ~ m ø d t e s ~ f o r ~ a t ~ m a r k e r e , ~ a t ~ d e ~ t y s k e ~}$ frierier hverken var i dansk, nordisk eller sønderjysk interesse. Stærkest indtryk under dette møde gjorde $H$. P. Hanssens tale. Hjemme havde jeg hørt så meget om denne mand, og min far var stadig i kontakt med ham. Endnu kan jeg se ham for mig, og høre hans slutbemærkninger, alt imens han slog næven ned $\mathrm{i}$ talerstolen: "I unge stil jer, når I rykker ud $\mathrm{i}$ fronten under P. Hiort Lorenzens banner. På det står der skrevet: For folkestyre, for retten til frit at tænke, tro og tale, for Sønderjyllands danskhed, for folk og fædreland. Lykkelig den ungdom, der får en stor opgave. Held og lykke følge jer i kampen. Jeg hylder og hilser ungdommen med kæmpevisens ord: Sejr i din hånd, sejr $\mathrm{i}$ din fod, sejr i alle dine ledemod «. På dette stævne fik jeg min nationale ilddåb.

Nogen tid efter fik jeg en henvendelse fra boghandler Algreen Petersen i Haderslev, der var DuG's sekretær i Haderslev amt, om jeg ville være med i arbejdet og sammen med andre tillidsmænd danne et lokalnævn for Øsby sogn. Det lykkedes hurtigt at finde de rette, og i fællesskab tegnede vi omkring 100 medlemmer i sognet.

Det blev begyndelsen til en lang række spændende oplevelser ved tillidsmandsmøder og udflugter til grænseegnen. Vi besøgte den nyetablerede Søgaard kaserne. I Jyndevad hørte vi om livet i et grænsesogn. Vi besøgte Rudbøl og DuG's kontor i Rørkær, hvor Peter Marcussen og kaptajn Bartholdy ledede arbejdet. Ret tidligt kom jeg også i personlig forbindelse med Marcussen. I et af mine breve opfordrede jeg til at DuG fik et medlemsblad. Det kom da også i 1936 som Folkung-Bladet.

Bekendtskabet med Marcussen blev livslangt, ja udviklede sig nærmest til et venskab. Det var mig derfor en stor glæde i 1974 i forbindelse med afslørin- 
gen af maleriet af Marcussen på Folkehjem at kunne være med i initiativet til udgivelse af Det unge Grænseværns historie, så vi fik de personlige oplevelser frem, mens en række mennesker, der i 1933 var med til at kalde sønderjysk ungdom til samling, endnu levede.

Der fulgte andre store stævner, i 1935 i Løgumkloster, det møde hvor C. P. O. Christiansen og Jørgen Bukdahl så stærkt fastslog den nordiske samhørighed. Temaet var sådan set fastslået allerede på Skamling med ordene »Ungdom i Nordens tjeneste«. Mottoet blev i de følgende år og ikke mindst efter 1940 så afgørende for den store organisation. I 1936 holdtes mødet på "Hjertehøj« i Graasten - trods voldsomme regnskyl. I efteråret 1935 deltog jeg $\mathrm{i}$ dagene 4.-6. oktober $\mathrm{i}$ et kursus på Rødding Højskole, arrangeret af Det unge Grænseværn. Forstander Hans Lund gav en bred orientering om Sønderjyllands historie. Claus Eskildsens belysning af den sønderjyske samhørighed med Danmark og Norden var i høj grad baseret på det materiale, der året efter kom i bogen Dansk Grænselære. Der var foredrag af pastor N. P. Nielsen, gdr. Johs. Juhl, Branderup, begge stærkt engageret i sønderjysk ungdoms- og idrætsarbejde. Også Hans Haarders belysning af Danmarks forhold til Tyskland gav et stærkt billede af situationen.

For en kun 19-årig var dette kursus af stor værdi. Det gav en mening med og et ståsted i det grænsepolitiske arbejde, hvor sigtet var at styrke den nationale forståelse blandt ungdommen i Danmark og ikke mindst i Sønderjylland. Spørgsmålet om forholdet til Norden optog mig derimod ikke så meget. Jeg forstod måske heller ikke helt de nordiske tankers rækkevidde. Peter Marcussens nordiske visioner stod jeg noget forbeholdent overfor.

Der var tilstrækkeligt at gøre i Sønderjylland, hvor det tyske mindretal ved Folketingsvalget i 1935 var gået frem med næsten 3000 stemmer, fra 9.886 til 12.617, samtidig med at antallet af tyske privatskoler steg til 58, og de tyske skoler - heri også de kommunale - nu besøgtes af over 4.000 elever. Dertil kom Vogelgesangs virksomhed med opkøb af gårde og billige lån til betrængte og i national henseende ikke alt for stabile landmænd. Det voldte os således personlig sorg, at en af vore slægtninge måtte sælge sin gård til en hjemmetysker. Aktionen blev oven i købet støttet fra dansk side. Som kreditforeningsdirektør P. A. Callø fortalte mig senere, for at undgå at denne tysker måske med Vogelgesangs hjælp blev placeret $i$ et af de $i$ forvejen truede sogne, hjalp man ham til en gård $i$ en i national henseende ufarlig egn.

Hertil kom imidlertid også noget helt tredje. Den ældre generation, der havde kæmpet for danskheden under tysk styre og forberedt Genforeningen, var ved at blive træt. Den følgende generation var mærket først af krigen, siden af den tiltagende økonomiske modgang. De havde mere end nok at se til, skulle de klare dagen og vejen. Derfor måtte det nu blive det næste slægtled, 
der tog kampen op. Den tillidsmandskreds, vi fik dannet i Øsby sogn, arbejdede godt. Og vi fik mange medlemmer. Kredsen bestod af læge Misfeldt, Øsby, senere gårdejer og amtsrådsmedlem Hans Simonsen, Hyrup, medhjælper og senere kornhandler i Øsby Jens Løbner, landmand Claus Knudsen, Årøsund, lærer Sigurd Oxholm, Hajstrup, landmand Theodor Ravn, Råde, og landmand Sv. Olsen, Årø.

Nok var jeg blevet klar over, at der bestod et vist modsætningsforhold til de gamle nationale foreninger, Sprogforeningen og Sønderjydsk Skoleforening, men dog især til Grænseforeningen, som måske frygtede, at de unges aktion ville føre til fornyet uro i Sønderjylland og især omkring grænsen. Her føltes det som en særlig anerkendelse, at H. P. Hanssen lige fra første færd støttede Peter Marcussen og dermed Det unge Grænseværn. Modsætningerne fortonede sig da også efterhånden.

\section{De danske i Flensborg}

Alt det, jeg nu har skrevet om de nationale forhold i Nordslesvig, kan godt tydes derhen, at vi havde så rigeligt at kæmpe med i forsvaret af den genforenede del af Sønderjylland, at Sydslesvig eller de danske i Flensborg egentlig ikke kom os ved. Det var dog ingenlunde tilfældet. Endnu sad grænsestriden dybt forankret hos mange. Selv folte jeg mig nok mest i overenstemmelse med $\min$ far, H. P. Hanssen og Martin Simonsen. Jeg var Aabenraa-mand, og grænsen af 1920 var for mig den eneste rigtige. Dog oplevede jeg, at der stadig fandtes et andet synspunkt, at grænsen i 1920 var trukket forkert, og at vi havde svigtet de danske syd for grænsen.

Derfor var det ganske ejendommeligt efter 1932 at møde det danske mindretal i Flensborg. Det var kun en beskeden flok. Far havde fået lejlighed i Burghof mellem Toosbüystraße og Marienstraße. Det danske samlingssted var »Hjemmet« i Mariegade, hvor 5., 6. og 9. distrikt holdt deres møder. Nu var det jo ikke alt for ofte, der blev tid til at komme til Flensborg. Alene den indførte visumtvang gjorde det besværligt. Men i julen var jeg der hvert år og deltog også i Slesvigsk Forenings julemøder, hvor enten pastor Noack eller pastor H. F. Petersen var faste talere. Når Noack trådte ind i salen, sænkede der sig straks en alvorsfuld, nærmest andagtsfuld stemning over forsamlingen. Han var jo alvorsmanden. Kom derimod H. F. Petersen, der straks startede med en vittig bemærkning, satte det omgående stemningen adskillige grader $\mathrm{i}$ vejret. Men også H. F. Petersen kendte til livets alvorlige sammenhænge. Et brev, jeg fik fra ham efter fars død, viser tydeligt, at også han kunne være en hjælper $\mathrm{i}$ alvorlige stunder. 
Far blev ret hurtigt engageret i distriktsarbejdet. Han var en habil taler, og hans muntre fortællinger fra enten Nordslesvig eller Flensborg blev benyttet til oplæsning. Derved kom han ud i en del flensborgske distrikter, ligesom han var ude i omegnen og enkelte gange nord for grænsen i Kruså, Kollund eller Bov.

Egentlig havde han ikke de helt store forventninger til et fortsat dansk mindretalsarbejde syd for grænsen. F.eks. anså han det som noget ret voveligt eller rettere naturstridigt, da der i 1935 oprettedes en dansk skole i Tønning.

Under mine besøg lærte jeg flere af hin tids danske personligheder at kende. Bedst nok sekretær Frederik Petersen og redaktør Tage Jessen. På møder i Nordslesvig havde jeg hørt flere talere fra Sydslesvig. Foruden de lige nævnte var det vandrelærer Gustav Lindstrøm fra Ladelund, lærer Hans Meng, Duborgskolen, gdr. Jørgen Søgaard, Jaruplund, og journalist J. N. Jensen, Flensborg Avis. Nu kom jeg også på besøg hos nogle af dem og desuden hos gdr. Peter Budach, Hornskov, i hvis stuer den danske skole i Jaruplund var startet i 1926. Jeg traf også økonom Nis Petersen i det danske forsamlingshus i Harreslev, lærer August Rattenborg i Kobbermølle og flere gange lærer Henry Thomsen i Langbjerg, som iøvrigt også var hyppig gæst hos os.

Også i Flensborg lærte jeg adskillige gode danske familier at kende. Sproget var nok det mest ejendommelige. Nogle snakkede sønderjysk og røbede måske derved deres oprindelige nordslesvigske herkomst, andre talte tysk eller ofte plattysk. Ja, det var faktisk sådan, at mens der i Den slesvigske Forenings distrikter nord for Nørretorv i reglen taltes dansk ved sammenkomsterne, var det tysk, der fortrinsvis benyttedes $\mathrm{i}$ byens sydlige og ostlige dele.

Hvordan gik så dette danske arbejde? Der var generalforsamling, ældreudflugt, lottospil og så et enkelt i reglen ikke særlig godt besøgt foredrag. Således kunne man godt opleve dem, der til et møde lige stak næsen indenfor og med bemærkningen "Vi ska inne kaffe ha i daw《 skyndsomst forsvandt igen. Den gratis kaffe var også dengang et trækplaster.

Fars breve fra disse år bærer tydeligt præg af, at han godt kunne ønske sig lidt større politisk aktivitet. Tage Jessen og Fr. Petersen kunne han godt acceptere, men han stod ret forbeholden overfor Ernst Christiansen, den mangeårige og yderst selvbevidste leder af Flensborg Avis. Hans ofte lidt overnationalt lyriske form var ikke hans stil. Hertil bidrog også den store afstand, der ofte føltes at være mellem den danske ledelse og de menige medlemmer i distrikterne. Trods alt var det jo dem, der bar de daglige byrder og tog slæbet og samtidig fik vanskelighederne, når de på grund af deres danskhed blev truet på deres arbejdsplads, eller der nægtedes dem en ellers berettiget understøttelse. I et brev kan jeg læse, at det vakte stor begejstring, da de to unge lærere Niels Bøgh Andersen og Hermann Tychsen kom ud i distrikterne for at underholde, 
og at de samtidig gik i opposition til de ældre og krævede ret for ungdommen til også at tale med. At de samtidig stillede sig skarpt afvisende overfor nazismen og alt dens væsen og krævede det samme af mindretalsledelsen, føltes yderst opmuntrende. Det føltes da også helt $\mathrm{i}$ overenstemmelse med denne linie, at lærer ved den kommunale danske skole i Flensborg, Hans Tønnsen nægtede at bruge Hitler-hilsnen. Derfor var redaktør Jacob Kronika heller ikke just manden, man var helt så begejstret for. Man syntes nok, at han omkring 1933 stillede sig lidt for venligt overfor det nye styre. Det var der endda nogle, der huskede, da Kronika i 1960 blev chefredaktør for Flensborg Avis.

De følgende års begivenheder kunne vi heldigvis knap ane $\mathrm{i}$ midten af 30 'erne. Men ingen var tryg ved situationen. For de danske syd for grænsen blev et besøg i Danmark altid som en kortvarig oplevelse af friheden. I sommeren 1936 var 5., 6. og 9. distrikt på udflugt til Ravsted. Jeg tog derud på cykel for at være sammen med far og vennerne fra Flensborg. Claus Eskildsen holdt et af sine spændende foredrag, og lærer Chr. Demuth og frue gav en fortrinlig oplæsning. For alle var det en god dag. For de danske i det ellers stærkt hjemmetyske sogn Ravsted (lille Tyskland) var det værdifuldt, at der netop hertil kom en flok danske fra den anden side grænsen. Danske i Ravsted og danske i Flensborg havde ikke så lidt at være fælles om.

Der var ofte en ganske egen stemning over danske møder syd for grænsen, selv om man hver gang måtte konstatere, at tallet af ubesatte stole var stigende. Ikke alle kunne jo klare det tiltagende tryk fra nazistisk side, selv om det danske mindretal officielt var fredet.

I 1935 fik jeg lejlighed til at deltage i et dansk årsmøde. Det var med en sær fornemmelse, omgivet af alt det nazistiske væsen, på Duborgskolen at overvære danske spejderes flagparade, og senere med sammenrullet Dannebrog at gå $\mathbf{i}$ optog til den gamle årsmødeplads ved Sortevej (nu dansk idrætsplads). Endnu mindes man de overbærende og spydige blikke, der mødte os fra fortovets tyske kødrand. Det opfattedes nærmest som et "nå, ja, lad dem dog, deres tid varer ikke så længe«. Talerne husker jeg ikke, kun at Ernst Christiansen og friseren Johs. Oldsen talte, ligesom vi på et møde på Duborgskolen havde hørt en status over situationen.

Og så holdt jeg min første tale i "Hjemmet«. Det var i 1934. Jeg deltog i en sammenkomst i anledning af Christian X's fødselsdag. Til Dannevirke i Haderslev skrev jeg et referat af festen. Der var samlet 160 mennesker i den smukt pyntede sal, rektor dr. Andreas Hanssen fra Duborgskolen holdt festtalen. Sangeren Saxtorp Mikkelsens fortolkning af Valdemar Rørdams sang om de kvalte klokker, de af tyskerne under 1 . verdenskrig til kanoner omstøbte sønderjyske kirkeklokker, gjorde stærkt indtryk. Som gæst nordfra blev jeg 
opfordret til at sige noget om Det unge Grænseværn. Det blev den første nationale tale, jeg kom til at holde.

Det var ellers ved at blive strenge tider. »Kanoner for smør " havde Hermann Goering proklameret, og rationeringen var begyndt på en række områder. Det var derfor helt naturligt, at kom man fra det velforsynede Danmark, havde man levnedsmidler med. Da jeg skulle hjem til jul 1935, var jeg særdeles velforsynet. Hvem tænker vel på tolden? Men toldvæsnets vågne øje var der, da jeg i Padborg var stået af toget for at vandre de sidste $\mathrm{km}$ ind til Flensborg. På Oksevejens dengang yderst beskedne toldstation ville de ikke uden videre lade mig passere med alle herlighederne. Der var kød, som ikke måtte indføres. Det var på en juleaftensdag slet ikke nogen morsom situation. Men heldigvis kunne også tyske toldere være forstående. Da jeg havde siddet i nogen tid, og toldlokalet efterhånden blev tømt, fik jeg at vide, at det jo kun var juleaften en gang om året, så lad gå for denne gang. Og skyndsomst tog jeg af sted. Juleaften var reddet. Jeg tænkte slet ikke på, hvad der ville være sket, dersom tolderne i min kuffert havde opdaget eksemplarer af "Hejmdal«, jeg havde lagt mellem tingene. Hejmdal var på den tid forbudt læsning i Tyskland.

\section{På Næsgård Agerbrugsskole}

Efter at far var flyttet til Flensborg, stod jeg egentlig ret alene i verden. Jeg måtte overveje to ting: Hvordan skulle jeg tilrettelægge min fremtid, og hvordan kunne jeg slippe ud af det tyske statsborgerskab? Det sidste var ikke mindst vigtigt - tysk værnepligt var jo indført i 1935.

I 1935-36 arbejdede jeg stadig ved landbruget, men på opholds- og arbejdstilladelse. Og selv om vor gode ven sognefoged Martin Simonsen altid anbefalede mine ansøgninger om forlængelse, og den efter nogle år kom til at lyde på ubestemt tid, var det ikke sikkert, at det ville fortsætte. For at understrege min interesse i engang at blive dansk statsborger var jeg efter råd fra Martin Simonsen optaget i den danske lægdsrulle og tog også i foråret 1936 til session. Her fik jeg imidlertid at vide, at som tysk statsborger kunne man ikke bruge mig.

I foråret 1936 traf jeg sammen med en slægtning, landbrugskonsulent Jørgen Rudbeck fra Grenå. Vi snakkede en del om mine planer. Jeg overvejede således et højskole- eller landbrugsskoleophold. Men ville det være nok til at sikre mig en ordentlig fremtid? Jørgen Rudbeck, der selv i sine unge dage havde været lærer på Næsgård Agerbrugsskole på Falster, foreslog derfor, at jeg skulle søge optagelse dér. Opholdet ville vare halvandet år, og det kunne give mig en frist, hvor jeg dels kunne søge udsættelse fra den tyske sessionspligt, dels forberede 


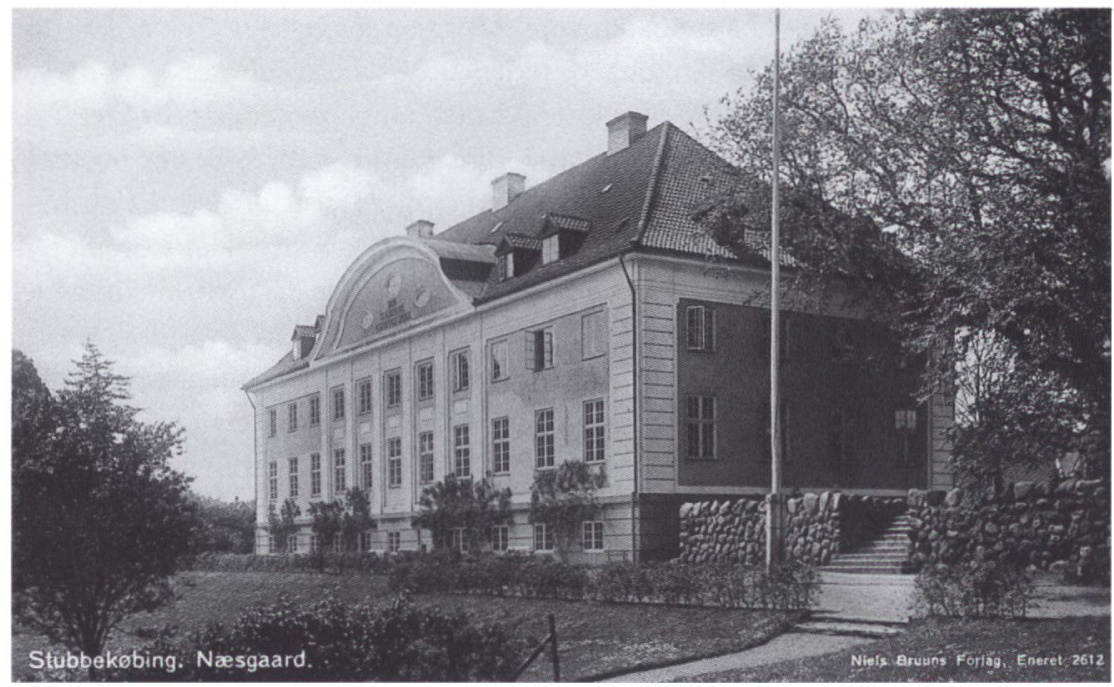

Nasgård Agerbrugsskole. Postkort 1936. Privateje.

eller undersøge mulighederne for at blive dansk statsborger. Men især ville jeg få betydelig større muligheder enten i det praktiske landbrug, eller dersom jeg ønskede at fortsætte på Landbohøjskolen.

Jørgen Rudbeck skrev selv til forstander H. J. Rasmussen på Næsgård, som var stærkt sønderjysk interesseret, og det lykkedes at blive optaget. Det skabte imidlertid et økonomisk problem. Selv om hele det 18 måneders ophold kun kostede $700 \mathrm{kr}$., var det alligevel mange penge. En årsløn for en voksen medhjælper lå dengang på ca. $800 \mathrm{kr}$.

Forgæves søgte jeg nogle legater, indtil der viste sig hjælp. Direktør P. A. Callø på Sønderjyllands Kreditforening, Martin Simonsen og Jens Brask erklærede sig rede til at sikre mig et studielån, og desuden kunne jeg - da min far kunne betragtes som dansk sydslesviger - regne med i det følgende år at få støtte gennem Dansk Skoleforening i Sydslesvig, ligesom også Sønderjydsk Hjælpefond kunne give tilskud. Endelig fik jeg at vide, at Det Classenske Fideikommis, som Næsgård hørte under, ville være til at snakke med, hvis det kom til at knibe.

Den 3. november 1936 startede jeg på Næsgård, og det blev en vidunderlig tid. Selve skoleopholdet var delt på tre skift, første vinter alene teoretisk undervisning sluttende med en eksamen. Sommerperioden var delt mellem praktisk arbejde $\mathrm{i}$ det $600 \mathrm{tdr}$. land store landbrug og hver anden uge teori og igen sluttende med en eksamen. Endelig var sidste vinter igen ren teori og en meget koncentreret undervisning, der fulgtes af en afsluttende eksamen. 
Undervisningen blev af største betydning for mig, og også det kammeratlige samvær betød meget. Men der blev desuden tid til andre interesser. Kort tid efter ankomsten til Næsgård tog jeg kontakt med amtsformanden for Det unge Grænseværn på Lolland-Falster, forstander Gregersen, Nørre Ørslev højskole, som Peter Marcussen havde anbefalet mig at opsøge. Jeg blev straks indbudt til et amtsnævnsmøde i Nykøbing, hvor jeg fortalte om arbejdet i Sønderjylland. Det førte til flere møder bl.a. et oplysningsmøde i Horbelev, hvor jeg holdt mit første egentlige foredrag.

På Næsgård blev der ved siden af den strengt teoretiske undervisning budt på en række orienterende foredrag. Det var således en stor oplevelse at høre redaktør Nicolaj Blædel gøre rede for den tilspidsede storpolitiske situation. Men også Sydslesvig hørte vi om ved Grænseforeningens rejsesekretær Lawaetz, som var i færd med at oprette en sønderjydsk forening i Stubbekøbing. Her var jeg med til den stiftende generalforsamling, hvor professor Vilhelm Andersen talte over emnet "Landsmandsskab«.

Men heller ikke Venstres Ungdom måtte forsømmes. En studiekreds i Vejringe, hvori deltog flere Næsgårdelever foruden unge fra egnen, gav en hel række nye kontakter. Også skriveri var jeg begyndt på. Jeg havde $i$ et års tid skrevet artikler til Dannevirke, og det fortsatte jeg med mod som honorar at få bladet sendt til Næsgård. Julen holdt jeg i Flensborg, og julefesten i »Hjemmet « gav god mulighed for at følge, hvad der rørte sig blandt danske i Flensborg.

\section{Dansk statsborger}

I februar 1937 fyldte jeg 21 år og havde dermed nået myndighedsalderen. Det betød, at jeg nu for alvor skulle sætte ind på at opnå dansk statsborgerskab. Jeg havde sikret mig to års udsættelse fra tysk militærtjeneste. I løbet af foråret fik jeg efter samråd med en sagfører i Stubbekøbing samlet de nødvendige papirer til en indfødsretsansøgning og dertil en række gode anbefalinger fra kendte folk i Sønderjylland bl.a. Peter Marcussen og Martin Simonsen. Desuden havde jeg sikret mig politisk hjælp, idet folketingsmand Einar Simonsen, Flovt, ville tage sig af det fornødne overfor indfødsretsudvalget og ikke mindst overfor indenrigsminister Bertel Dalgaard.

Der var nemlig et men i denne historie. Indfødsretsloven var omkring 1935 blevet skærpet, så der nu krævedes 15 års ophold i Danmark, foruden at man beherskede det danske sprog og viste interesse for danske samfundsforhold. Det sidste kunne jeg nok klare, men jeg havde jo kun boet i Danmark i 10 år. Resultatet blev da også $\mathrm{i}$ første omgang et afslag. 
Det skulle jeg imidlertid ikke lade mig slå ud af, mente Einar Simonsen, der fik mobiliseret andre rigsdagsmedlemmer, ligesom far kontaktede de sønderjyske rigsdagspolitikere Hans Jefsen Christensen og I. P. Nielsen, Dynt. Også fra Næsgård ydede man hjælp. Både forstander Rasmussen og lærer Lauridsen optog kontakt med rigsdagsmedlemmer fra Lolland-Falster, ikke mindst med senere trafikminister Victor Larsen, hvis søn selv var elev på skolen. Men der var fortsat afslag. Indenrigsminister Dalgaard motiverede det overfor Einar Simonsen med følgende ord: "Man kan ikke fratage en os venligsindet nation dets værnepligtige«. Sagt i 1937, da uvejrsskyerne fra syd blev stadig mere truende!

I påskeferien havde jeg været på en cykeltur til Sønderjylland for at hilse på gamle venner, og i sommerferien 1937 valgte jeg at tage syd om til Flensborg. Ved nattetid tog jeg færgen fra Gedser til Warnemünde og så gik det ellers på cykel gennem Mecklenburg og Holsten til Flensborg. Overalt var der militær og naziformationer, folk der talte om den nye tid, og hvad der kunne være $i$ vente, enten en ny gloria eller et kaput. Men det sidste sagde man ikke højt. Jeg fik også aflagt mit første besøg på de gamle Danevirkevolde og var på sejltur til Lyksborg. Overalt mærkedes en vis knugende stemning, så det føltes som en lettelse, da jeg efter endt ferie igen kunne passere grænsen ved Kruså.

Imidlertid lurede det jo stadig med indfødsretten. Hvor alvorligt det var, blev jeg klar over, da jeg under et juleophold i Flensborg i 1937 ville på et kort besøg i Haderslev. Lige som jeg skulle af sted, ringede det på døren. Det var politiet, som skulle hente mit pas. Her hjalp ingen gode ord, men jeg kunne gå med på politipræsidiet for at gøre indsigelse. Selvfølgelig gjorde jeg det. Jeg havde jo god samvittighed, og på spørgsmålet - og nu var det Gestapo, der tog mig i forhør - om jeg søgte dansk statsborgerskab, kunne jeg roligt svare, at det havde jeg nok overvejet, men der var ingen muligheder. Jo, for jeg kendte vel mine pligter overfor Das Vaterland, fik jeg at vide. Under henvisning til min udsættelse fra militærtjenesten, og at jeg skulle tage landbrugseksamen for at blive Diplomlandwirt, fik jeg omsider passet igen.

$\mathrm{Nu}$ var det bare med at komme nordpå. Ved grænsen blev der kropsvisitation. Og letsindig som man er i den alder, havde jeg ikke tænkt over, at jeg i lommen havde et brev til landstingsmand Jefsen Christensen med en indtrængende anmodning om hjælp til at blive dansk statsborger. Det var lige ved middagstid, og den herre, der kunne oversætte danske breve til tysk, var "zu Tisch «, hjemme at spise frokost. Da rutebilen desuden ventede, og jeg ikke havde bagage med og kunne bedyre, at jeg kom tilbage i løbet af aftenen, fik jeg lov at rejse videre. Men brevet beholdt de. Det blev iøvrigt med censurmærke af de korrekte tyskere sendt videre til Jefsen Christensen, som undrede sig noget over slig ungdommelig letsindighed. Det blev sidste gang, jeg passerede grænsen med tysk pas. 
Velankommet til Haderslev fik jeg gode venner til at skrive til far, at jeg pludselig var blevet alvorligt syg og derfor ikke var i stand til at rejse, og om han ville sende min bagage til Haderslev. Han blev selvsagt noget forskrækket ved tanken om, at han skulle over grænsen med min kuffert. Men det gik heldigvis godt. Jeg var nu klar over, at jeg måtte holde mig væk.

Vinteren var ved at gå på hæld, og jeg kom godt gennem den afsluttende eksamen. Nu måtte jeg finde på noget at bestille. At komme på Landbohøjskolen havde rent økonomisk lange udsigter. Det traf sig da så heldigt, at jeg fra Gunnar Kloppenborg Skrumsager fik tilbud om at komme til Bejstrupgaard $\mathrm{i}$ Københoved. På den måde kom jeg til en på alle måder dygtig landmand og kunne forberede mig til en mere ansvarlig stilling.

Den 29. marts 1938 sluttede vi på Næsgaard, og den 30. rejste jeg til København, hvor jeg straks tog til Christiansborg spændt på at høre, om der var kommet en lysning i min sag. Hos Jefsen Christensen fik jeg besked om, at netop samme formiddag havde Bertel Dalgaard omsider bøjet sig og var gået med til, at mit navn kom på den liste, der om eftermiddagen skulle behandles i Landstinget som lov om indfødsret.

Stor var min glæde og lettelse. Endelig var jeg sluppet for det pres, der uvilkårligt havde hvilet på mig. Jeg havde været afskåret fra at vise mig $\mathrm{i}$ Flensborg for slet ikke at tale om, hvad følgen ville være blevet, da tyskerne den 9. april 1940 besatte landet. Jeg kunne forblive i Danmark og kunne rejse til Københoved, den egn man også kaldte Sønderjyllands »ideelle hjørne«.

\section{I »det ideelle hjørne«}

Nu skulle jeg altså fortsætte min landbrugsuddannelse $i$ et absolut eftertragtelsesværdigt lærested med en meget fin sortbroget kvægbesætning. Bejstrupgård var efter rigsdansk mål en proprietærgård, men proprietærer ville disse sønderjyske storbønder ikke være.

Det kunne føles lidt mærkeligt, at jeg, der ellers mest havde færdedes i udprægede »Aabenraa-kredse«, nu fik plads hos familien Kloppenborg Skrumsager, en af Flensborgsagens varmeste forkæmpere. Her i Københoved fik jeg flensborgere på nærmeste hold. Som nabo havde vi Bennetgård, den i 1921 afdøde kendte sønderjyske fører J. N. H. Skrumsagers gård, som datteren Jutta Skrumsager i 1936 lod indrette som hvilehjem for ældre sydslesvigere. Her mødte jeg jævnligt gamle bekendte fra Flensborg. At Flensborg Avis nu også blev daglig læsning gav uvilkårligt en berøringsflade til danskheden i Flensborg, som jeg ellers kun kendte fra mine spredte besøg hos far.

Hertil kom, at Røddingegnen betragtedes som en af Sønderjyllands mest 
danske egne. Skrave sogn, som Københoved hører til, lå ved folkeafstemningen i 1920 i toppen med 97\% danske stemmer. Her rejstes i 1892 Sønderjyllands første forsamlingshus. Nu var der også forsamlingshus i Københoved. Her boede kendte folk som Nicolaj Ludvigsen, formand for den Nordslesvigske Landboforening, Mads Gram, tidligere folketingsmand for Venstre valgt i 1920 og nu formand for Venstre i Sønderjylland og for Fællesledelsen af kvægavl i Sønderjylland. Der var ikke langt til Rødding med højskolen, til det historiske samlingssted i Skibelund krat eller til Askov. Egnen var stærkt præget af Rødding frimenighed og et blomstrende folkeligt arbejde blandt såvel ældre som unge.

Det lovede jo godt. På den store gård var der nok at rive $\mathrm{i}$, og jeg trængte til efter halvandet års skoleophold igen at tjene lidt penge. Men der var som sagt også mange andre udfoldelsesmuligheder. Allerede den første måned deltog jeg i VU-møde i Rødding, hvor senere minister S. P. Larsen talte på højskolen. Der var folkelige møder i Københoved forsamlingshus. Ellers tog jeg på cykelture i omegnen.

På Rødding højskole holdt Hans Lund sine månedsmøder, som jeg ofte deltog i. Det unge Grænseværn holdt det år sit årsmøde i Haderslev, og på Valdemarsdagen var vi i Skibelund krat, hvor Hans Lund, Rødding og forstander Overgaard, Ladelund, talte om stavnsbåndet. Det var jo 150 året for stavnsbåndets ophævelse. Her opførte Askovlærere Holbergs "Erasmus Montanus«, og sjældent har jeg oplevet Erasmus så levendegjort som i højskolelærer Bo Ruds fremstilling.

Som nævnt havde vi Hvilehjemmet Bennetgård som nabo. Jeg aflagde jævnligt besøg for at hilse på sydslesvigerne. En fittig gæst var pastor Niels Bundgaard fra Skrave, som jeg senere, da han blev præst i Sydslesvig, først i Kappel og siden i Slesvig, fik nær kontakt med.

Imidlertid begyndte uvejrsskyerne for alvor at trække sammen over Europa med Hitlers krav om Sudeterlandet. I september 1938 skulle jeg nogle dage til Flensborg, hvor jeg kunne fejre både min fars fødselsdag den 24. og Christian $X . s$ fødselsdag den 26. september. Kongens fødselsdag fejredes på Flensborghus. Stemningen var tydeligt trykket, og jeg husker, far nævnte, at det føltes som i de sidste julidage i 1914, da 1 . Verdenskrigs udbrud var i vente. Alle spurgte, om det mon ville lykkes at afværge en ny katastrofe. Forhandlingerne i dagene forud tegnede ikke til, at Hitler ville ændre sine krav. Det prægede så tydeligt denne aften.

Journalist J. N. Jensen ledede mødet, og jeg husker, at der pludseligt blev meddelt, at faren måske var ved at drive over. Det blev oplyst, at ville Tyskland trods alle den britiske premierministers anstrengelser angribe Tjekkoslovakiet, ville Frankrig være nødt til straks at komme dette land til hjælp, og Storbritan- 


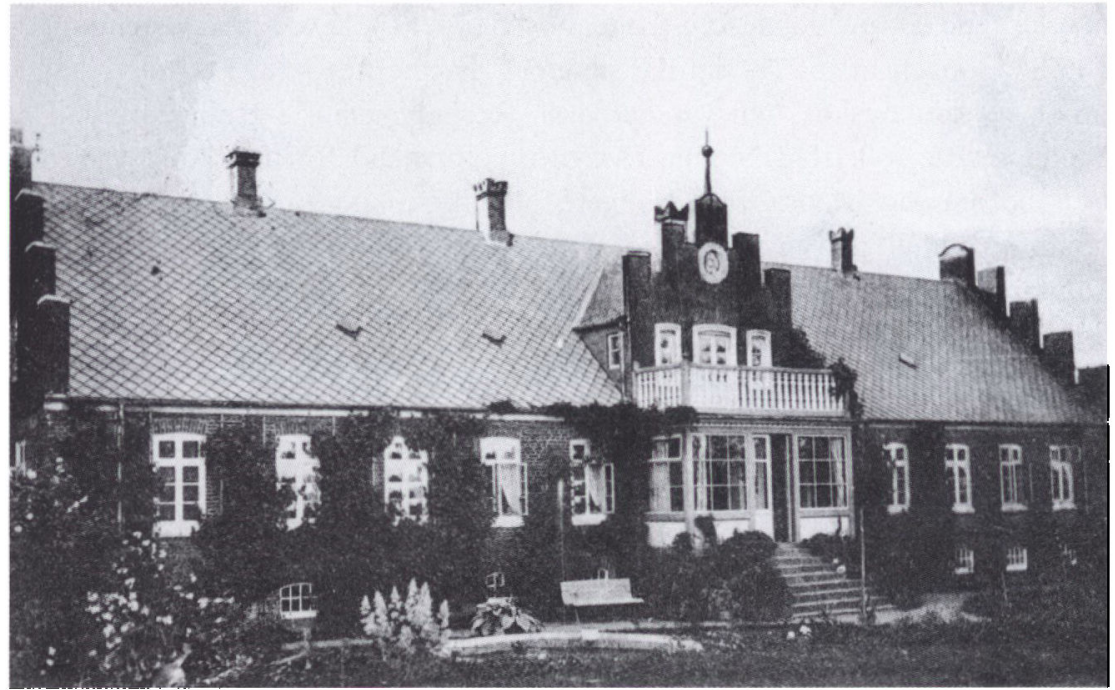

Bejstrupgård i Kobenhoved. Postkort 1914. Institut for sonderjysk lokalhistorie.

nien og Rusland ville stå ved Frankrigs side. På Flensborghus lettede meddelelsen unægtelig på stemningen.

Fra efteråret 1938 husker jeg to ting. Det ene var, at Mads Gram for første gang siden bruddet med H. D. Kloppenborg Skrumsager over grænsestriden i 1920 igen satte sine ben på Bejstrupgård. Mads Gram var ikke for ingenting en stædig sønderjyde. Da han nu i forbindelse med et eller andet lokalt anliggende begav sig til Bejstrupgård, blev der $\mathrm{i}$ høj grad lagt mærke til netop dette besøg. Det andet blev mund- og klovsygen, der grasserede voldsomt i denne eftersommer. Heldigvis var kvægsygen da så udbredt, at man undlod at slagte hele besætninger, hvilket ville have været slemt netop for den fine avlsbesætning på Bejstrupgård, hvor man netop denne sommer som et af de første steder $\mathrm{i}$ landet havde eksperimenteret med kunstig sædoverførsel. Det var ikke behageligt at passe dyrene, som var hårdt angrebne af sygdommen.

\section{Skovgård i Hammelev}

Til 1. november 1938 skiftede jeg plads. Kloppenborg anbefalede mig til Hans Skau på Skovgård i Hammelev, og det skulle vise sig at blive et godt bytte. Jeg havde fået en mængde praktisk viden, som jeg nu kunne udnytte det nye sted. Inden jeg forlod Bejstrupgård, holdt Gunnar Kloppenborg en fest i den sal, der havde været mødestedet for folk i Københoved og Skrave. 


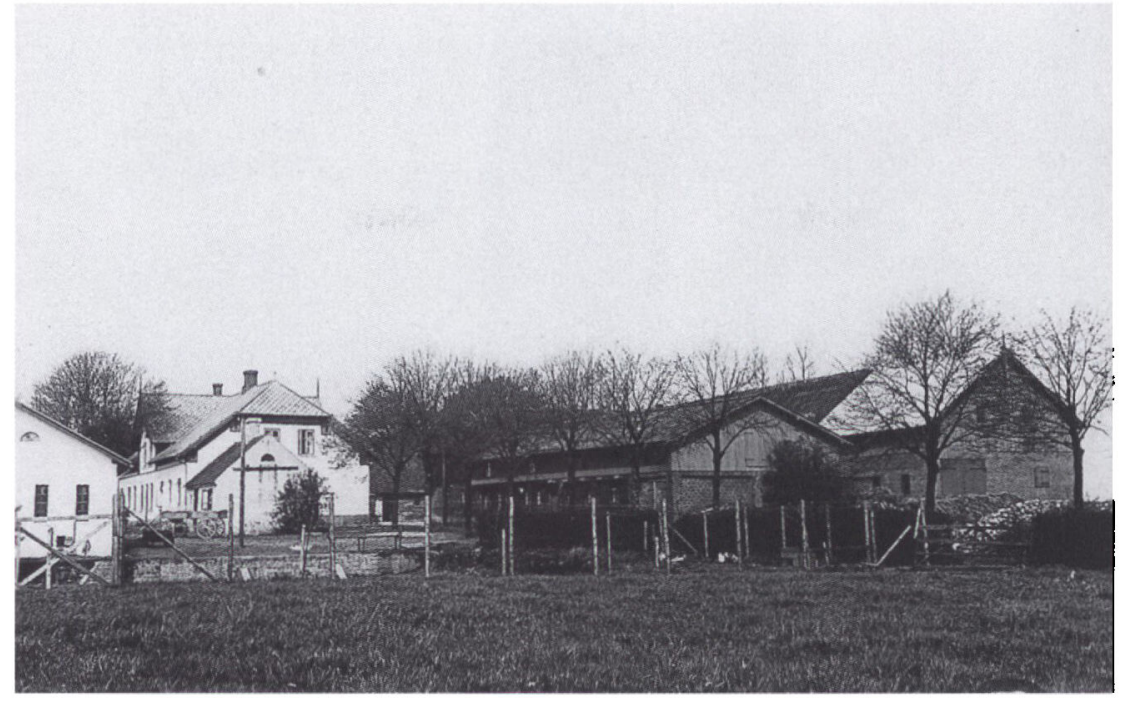

Skovgaard i Hammelev. Foto 1920 'erne i privateje.

Skovgård blev i nogle år nærmest et hjem for mig. I første omgang var jeg der som forvalter fra november 1938 til november 1942, og i vinteren 1944-45 passede jeg igen arbejdet, samtidig med at jeg havde andre gøremål. Det blev derfor stedet, som jeg hele tiden vendte tilbage til, så længe Anna og Hans Skau levede.

Til Skovgård hørte et samlet areal på godt 100 ha. heraf ca. 24 ha. skov og desuden en parcel $\mathrm{i}$ det netop genopdyrkede område $\mathrm{i}$ Hindemade ned mod Haderslev Dam. Markerne lå godt samlet omkring gården. Ledelsen af en sådan gård var et stort ansvar. Jeg følte mig dog hurtigt hjemme på gården. Straks forste dag efter en tur rundt $i$ alle marker meddelte Hans Skau, at nu tog han af sted i nogle dage. Så måtte jeg i øvrigt selv finde ud af at tilrettelægge arbejdet. Der var nok at tage fat på. Der var efterårspløjning, roer, der skulle køres sammen, og korn, der skulle tærskes. Jeg var alligevel glad for den tillid, Hans Skau viste mig fra første dag.

Som medarbejdere havde vi to karle og en fast husmand, og jeg kunne trække på yderligere hjælp til arbejdet i skoven eller til særlige opgaver. I stalden rådede en gift fodermester over ca. $30 \mathrm{køer}$ foruden opdræt og en flok stude. Det var dog ikke kreaturerne eller grisene, Hans Skau gik mest op i. Hestene kom i første række, og hestebestanden omfattede i reglen en hingst, to-tre følhopper og nogle plage, som gerne skulle udvikle sig til enten kommende præmiehingste eller følhopper. 


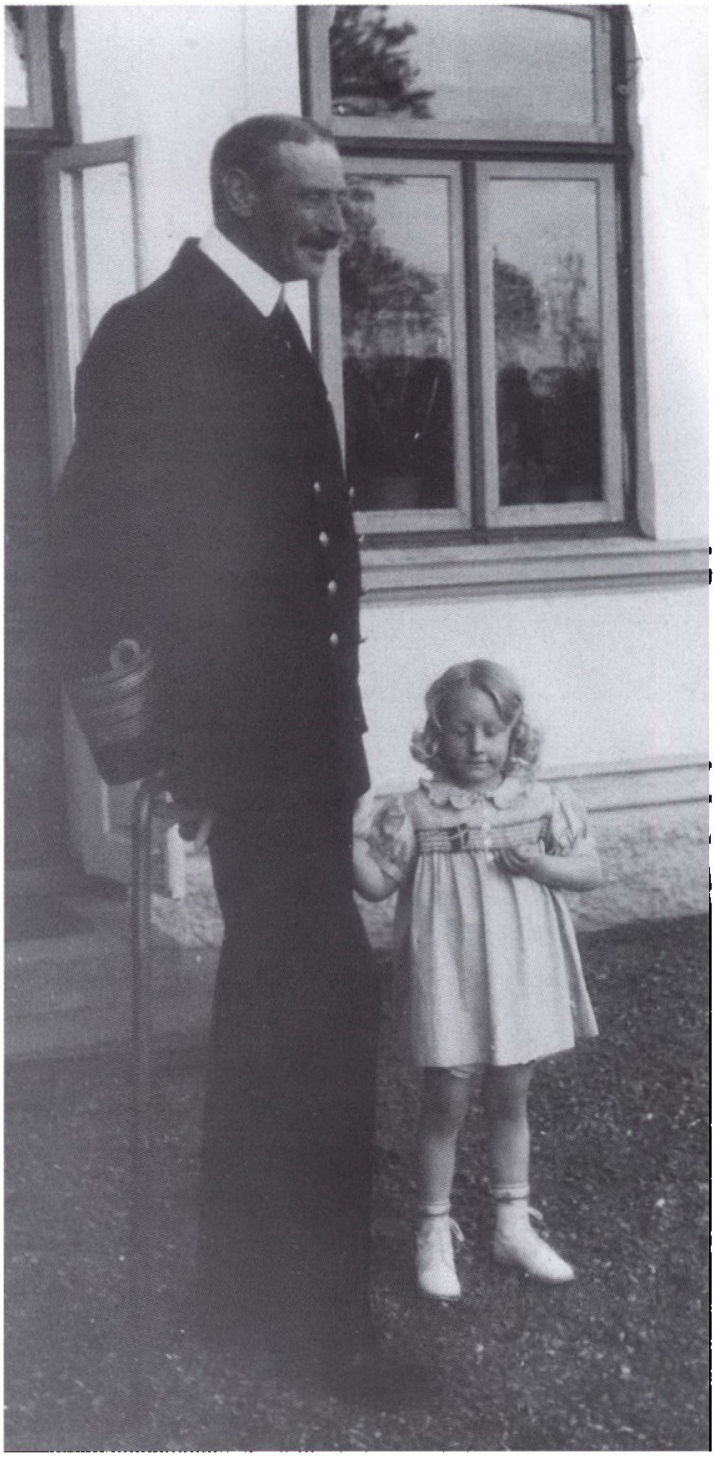

Kong Christian $X$ aflagde besog på Skovgaard i sommeren 1938. Han blev fotograferet sammen med et harnebarn af Hans Skau.

Skauslægten var en af denne egns gamle slægter og havde altid været stærkt nationalt bevidst. Den kendte sønderjyske fører Laurids Skau hørte til en gren af slægten. Hans Skau selv havde fra 1907 til 1932 været medlem af bestyrelsen i Haderslev Amts Landboforening. Både han og foreningens formand gdr. Martin Viuf, Sillerupgård, måtte da vige for presset fra LS, som ønskede en 
skarpere politisk holdning fra landboforeningernes side. For sit mangeårige virke indenfor landbruget var Hans Skau netop samme sommer i 1938 udnævnt til Ridder af Dannebrog, ligesom Christian X. under et af sine årlige Sønderjyllandsbesøg i denne sommer havde været gæst på Skovgård.

Hans Skau var kendt som opdrætter indenfor den jyske hesterace. Som dommer ved hoppekåringer $\mathrm{i}$ hele Sønderjylland og deltager $\mathrm{i}$ de fleste jyske hingstekåringer og desuden selv formand for Hammelev sogns hesteavlsforening var han godt kendt blandt jyske hesteavlsfolk.

Selv om det helt naturligt kom til megen hestesnak, blev nationale og politiske emner ikke forsømt. På det nationale område efterlevede Hans Skau i høj grad de ord, der stod indgraveret i en tavle over hans skrivebord:

Du skal vogte de sagn og den dejlige sang, vi $i$ arv efter fædrene fik.

Du skal lukke dit hjerte for trældom og tvang og din dør for de fremmedes skik.

A. D. Jørgensens $» 40$ fortællinger af Fædrelandets Historie« og P. Lauridsens værk »Da Sønderjylland vågnede« var bøger, Hans Skau ofte under samtaler drog frem. Desuden havde han helt tilbage $\mathrm{i}$ årene før 1. Verdenskrig ført dagbøger, og det blev for mig spændende at læse den kloge bondes vurdering af tidens tildragelser. Politisk holdt han sig til partiet Venstre, og her var han både formand for Hammelev sogns Venstreforening og desuden næstformand i Røddingkredsens Venstre. Men derudover havde han mange andre gøremål bl.a. som bestyrelsesmedlem i Dansk Skatteborgerforening og Jysk Haglskadeforsikring. Jeg fik et stærkt indtryk af Hans Skaus mange gøremål og af hans store viden om problemer af vidt forskellig karakter. Sammen med en grog og en god cigar blev det til mange hyggelige og opbyggelige timer.

I driften var det ikke mindst hestene jeg skulle tage mig af. Der blev også handlet heste, og i reglen var det nye avlsdyr, vi fik. Ikke underligt, at statskonsulent August Kjær fra De samvirkende Jydske Hesteavlsforeninger var en kærkommen gæst. Hvert år holdtes et mønstringskursus, hvortil også egnens unge var indbudt. I de tider var det absolut ikke ligegyldigt, hvordan hesten tog sig ud, og hvordan man var i stand til at præsentere den enten overfor besøgende ved dyrskuer eller kåringer. Allerede kort tid efter min start holdtes et mønstringskursus under ledelse af mønstringslærer og senere hingstekommissionær Chr. Rasmussen fra Vejen.

Mund- og klovsygen ramte vor kvægbesætning, en sygdom de svære korthornskreaturer kunne have svært ved at klare. Takket være mine erfaringer fra Bejstrupgård slap vi dog nogenlunde nådigt. Endelig var der det store skov- 


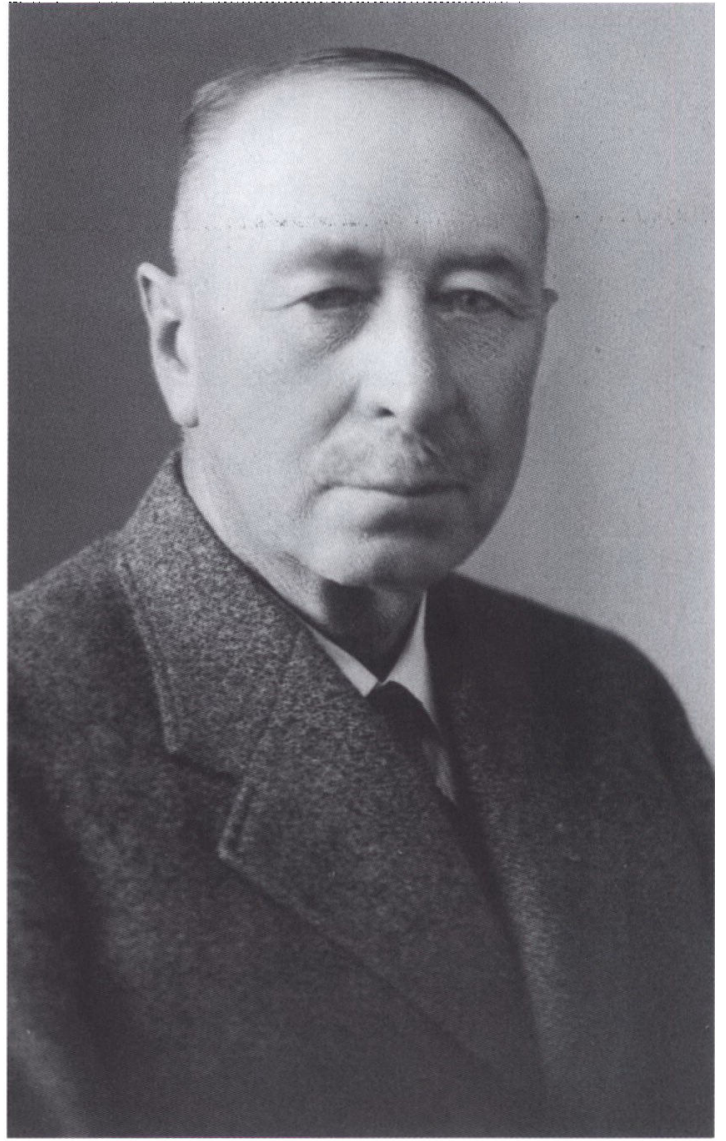

Hans Skau (d. 1952), Skovgaard. Foto i privateje.

areal, der skulle passes, og hvor et par mand gik meget af tiden. Der skulle både ryddes og fældes og desuden plantes nyt, og der blev gjort klar til den årlige skovauktion.

I julen 1938 rejste jeg igen hjem til Flensborg. Da min far som næunt var stærkt politisk interesseret, og hverken den tyske presse eller Flensborg Avis kunne skrive, hvad den gerne ville, var rigsdanske aviser selvsagt kærkommen læsning. Jeg havde taget flere aviser med og også nogle eksemplarer af et på den tid i Holland trykt blad Neuer Vorwärtz, der udkom som en afløser af den forbudte tyske socialdemokratiske avis Vorwärts. Bladet var selvfølgelig forbudt i Tyskland, men lagt ind i et par eksemplarer af det danske naziorgan Nationalsocialisten, nåede de upåtalt over grænsen. Far blev glad for både de danske og de tyske aviser. Nazibladene røg omgående i kakkelovnen. 
Min ret frie stilling gav gode muligheder til at lære egnen at kende, ligesom jeg kunne deltage i møder i Det unge Grænseværn, Venstres Ungdom og Hammelev Ungdomsforening, til gymnastik, ringriderfest og folkedans. Der var landbrugsfaglige møder og arrangementer. Det gjaldt hele tiden om at holde sig à jour.

Skovgård var et gæestfrit hjem. Hvordan den rare og i modsætning til Hans Skau meget hjemmeværende og samtidig stilfærdige Anna Skau klarede tingene, har ofte undret mig. Der var altid plads til uanmeldte besøg. Til de faste gæster hørte folketingsmand Jørgen Gram, Gabøl, selv en stor hesteopdrætter og nu kredsens folketingsmand, der hurtigt skabte respekt om sig som politiker. Der var sognepræsten, pastor Hans Hamlev, som nok ikke var den store sjælesørger men til gengæld et muntert menneske, alle kunne lide. Jeg fik med tiden megen glæde af besøg i Hammelev præstegård.

Vor sognerådsformand og samtidig amtsrådsmedlem Jørgen Uldall, Styding, hentede ofte gode råd hos den erfarne Hans Skau. Her kom grosserer Peter Michaelsen, Lunderskov, hvis kone Margrethe engang havde været ung pige på Skovgård. Han var næstformand i Grænseforeningen. Til de jævnlige gæster hørte også domæneforvalter Peter Refshauge, tidligere gårdejer i Oksbøl.

En lille episode, fortalt af Peter Refshauge fra hans tid som landråd, siger måske også lidt om de nationalpolitiske stemninger, der rådede i tiden op mod afstemningen i Sønderjylland i 1920. En dag fik Refshauge på sit kontor besøg af en fransk officer. De franske alpejægere var rykket ind i Haderslev for at sikre ro under afstemningen. Selvsagt kom samtalen hurtigt ind på den nationalpolitiske situation. Som bekendt nærede Frankrig ingen blide følelser overfor det slagne tyske kejserrige. Hvorfor egentlig holde afstemning, mente den franske officer, nej man skulle gøre som Frankrig, der uden mere snak tog Elsass-Lothringen tilbage. Og mens han trak sin sabel og slog den ned i gulvet, udbrød han »abschneiden«, bare skære det røvede fra igen, og her mente han jo nok, at hele Slesvig burde være vendt tilbage. Bedre havde tyskerne ikke fortjent det. Det var dog ikke helt i overenstemmelse med hverken Refshauges eller den almindelige nordslesvigske linie, som holdt på folkenes selvbestemmelsesret som det afgørende. Men mange år efter - påstås det - kunne spor af det franske sabelhug endnu ses i Haderslevamtmandens kontor.

Min »familiære« stilling, gjorde, at jeg praktisk talt altid kunne være til stede, når der var gæster, og det var hver gang spændende at lytte til de forskelliges oplevelser eller kommentarer til den øjeblikkelige situation.

Jævnligt kom også sønnen Jens Skau og hans kone Anne Marie født Kloppenborg-Skrumsager, nu forpagterfolk på Nygård domæne i Øster Lindet. Desuden var der de mange hestefolk, der enten kom for at bese vor egen bestand eller ønskede at udveksle erfaringer. Blandt dem var Andreas Jensen 
fra Gabøl. Under første Verdenskrig var han stor hestehandler, men ved krigens afslutning brændte han inde med en betydelig sending, der var opkøbt til den tyske hær, og det slog ham økonomisk ud. Nu vegeterede han nærmest hos Jørgen Gram og var hans opkøber eller sælger af avlsmateriale, og da han var en stor hestekender, kunne Hans Skau også ofte bruge ham til visse ærinder.

Også konsulent Jørgen Frank kom af og til. Han var dog næppe tilfreds med Skovgårds korthornsbesætning. Derimod havde konsulent Mathias Nissen, der også var jysk hestemand, en stor stjerne i huset.

De, der endnu husker Hans Skau, vil nok mindes ham som den gode fortæller. Han kunne et utal af historier om mennesker, han havde mødt. Han var en fremragende taler, og både $i$ samtale og foredrag kunne han indflette lange citater af dansk digtning.

\section{Fars død i KZ-lejren Oranienburg}

I påsken 1939 var jeg på besøg i Flensborg, og i de følgende uger undrede det mig, at jeg intet hørte fra far, som ellers skrev flittigt. Den 17. maj skulle jeg til et VU-møde i Haderslev, hvor VU's landsformand Poul Thisted Knudsen ville tale. På vej ind til »Harmonien«, hvor mødet holdtes, traf jeg redaktør N. J. Nielsen fra Dannevirke, som lidt bekymret spurgte, om jeg vidste noget om, hvordan min far havde det. Jeg vidste intet, hvorefter han spurgte, om jeg da slet ikke havde hørt, hvad der var sket. At han allerede den 2. maj var blevet arresteret. På bladet havde de fra Kruså fået besked om at indstille enhver forbindelse til ham. Han var jo stadig skribent til bladet. Det viste sig senere, at et brev sendt til mig fra Flensborg, ikke var sluppet gennem den tyske censur.

Jeg tog kontakt til bekendte heriblandt politifolk i Kruså, og de kunne bekræfte det skete. Dog gjorde jeg nok selv klogt i at holde mig væk fra Flensborg. Det var aldrig til at vide, hvordan tyskerne ville reagere. Det var kun et år siden, jeg var sluppet af med mit tyske statsborgerskab. Også det danske konsulat i Flensborg og udenrigsministeriet i København henvendte jeg mig til, men forgæves. Far var tysk statsborger, og selv om han tilhørte det danske mindretal, kunne der intet gøres. De gav mig dog den trøst, at fængslingen formentlig kun blev af kort varighed, da man fortsat beholdt ham i Flensborg.

Der skulle dog kun gå godt en måned, så blev han overført til KZ-lejren Oranienburg, det senere Sachsenhausen. I oktober fik jeg så brev, at far var død den 9. oktober. Som dødsårsag blev angivet kredsløbsforstyrrelser, og så kunne man jo tænke sit. »De slog ham ihjel, de Sataner«, skrev forfatteren 


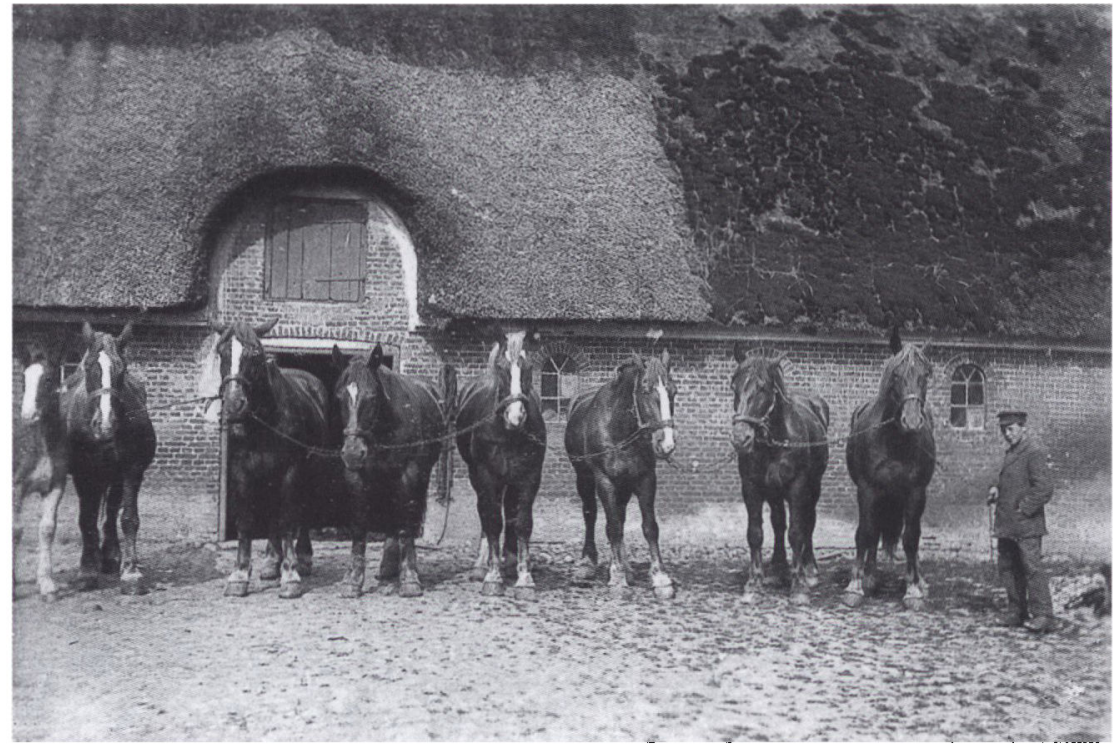

Skovgaard var kendt for sine heste. Her en hesteopstilling o. 1920. Privateje.

dr. Gudmund Schütte til mig nogen tid efter. Han havde også tidligere haft nær kontakt med far, og i flere breve fortalte han om de besøg, han havde aflagt $\mathrm{i}$ vort hjem $\mathrm{i}$ Berlin.

Ja, så var jeg blevet hjemløs. Men stor var trods sorgen min glæde, da Hans Skau kom ind til mig og sagde, at herefter måtte jeg betragte Skovgård som mit hjem. Det var et så smukt træk, at jeg aldrig glemmer det.

\section{Folketingsvalg 1939 - mit politiske ståsted}

Selv om der var nok at se til i det store landbrug, kunne der godt blive tid til en del andre gøremål. I juni 1939 deltog jeg i VU's landsstæune i Århus. Vi deltog i dyrskuer og ved hoppe- og hingstekåringer.

1939 var også året for folketingsvalget den 3. april. I Sønderjylland satte det tyske mindretal alle sejl til. Det var nu eller aldrig, skulle kravet om Nordslesvigs tilbagevenden til Tyskland lykkes. Tonen var ikke blid. „Führer mach uns frei«, havde Jens Møller frejdigt udtalt ved et valgmøde i Tønder. Man havde indsat uniformerede unge fra den nationalsocialistiske førerskole i Plön, som skulle forstyrre de danske valgmøder bl.a. ved at smide tyske flyveblade ind $\mathrm{i}$ salen. Vi oplevede da også under et valgmøde i Hammelev forsamlingshus, 
hvor Jørgen Gram og Peter Nielsen, Refsø, talte, at det pludselig væltede ind med tyske flyveblade. Mere skete der heller ikke. Fredsforstyrrerne havde skyndsomst taget flugten.

Både De sønderjyske Danske Samfund og Det unge Grænseværn var i fuldt beredskab, og resultatet blev, at Slesvigsk Parti kun gik frem med 2.400 stemmer til 15.016. Valgdeltagelsen blev på 92,4 pct. eller endda en anelse mere end de 91,5 pct. som deltog i folkeafstemningen i 1920. I Hammelev sogn faldt der 31 tyske stemmer, og det var til at bære.

Der blev heller ingen genforening med Tyskland. Til gengæld kunne hele den tilspidsede storpolitiske situation nok give anledning til bekymringer. Den 1. september marcherede tyskerne ind i Polen. Krigen var en kendsgerning.

Selv om vi i første omgang ikke havde krigen på nærmeste hold, mærkede vi ret hurtigt konsekvenserne. Sikringsstyrken blev indkaldt, og på Skovgård fik vi en ganske betydelig belægning. Den private bilkørsel ophørte. Det kom os lidt $i$ vejen, fordi vi netop i september havde planlagt en marsktur for at se på de hingstplage, der græssede derude. Imidlertid havde fabrikant Fr. Becker på Kød- og Benmelsfabrikken i Hammelev (nu Sønderjyllands Kunst- og Kulturcenter) stadig kørselstilladelse, og vi kom på en ganske dejlig tur rundt $\mathbf{i}$ Tønderegnens marskenge. Alligevel gjorde det et mærkeligt indtryk at se den stængte grænse og tyske bevæbnede poster patruljere langs grænsepigtråden.

Som det er fremgået, har jeg altid interesseret mig for politik. Jeg voksede op i et socialdemokratisk hjem, og socialismens teorier var noget nær et evangelium for min far, men selv følte jeg ikke, at jeg ville følge samme spor. Så tidligt som i 1934-35 kom jeg med i Venstres Ungdom, og det slet ikke, som det ofte påstås om VU-medlemmer, for ballernes skyld, selv om de kunne være ganske sjove. Det var Venstres politiske mål jeg følte mig tiltrukket af.

Jeg blev Venstremand. Mange af mine slægtninge på Haderslevegnen var derimod konservativę. Min afholdte lærer i Hajstrup var radikal, og min landbrugskarriere startede jeg hos en retsstatsmand. Jeg havde ofte overværet de forskellige partiers politiske møder og navnlig interesseret mig stærkt for diskussionen partierne imellem. Men hverken den socialdemokratiske eller konservative politik tiltalte mig. Heller ikke Dansk Samling, som adskillige af mine venner fra Det unge Grænseværn var stærkt optaget af, og som jeg endda hørte fortolket i Arne Sørensens udlægning, kunne overbevise mig. Her måtte jeg give Jørgen Bukdahl ret, da han engang karakteriserede dette parti som et åndeligt januarudsalg, en blanding mellem Jesus og Madsen Mygdal med for meget ballon og for lidt ballast.

Måske gjorde det sit, at jeg i mine år i Flovt levede nær op ad stærkt engagerede Venstrefolk som folketingsmand Einar Simonsen, sognefoged Martin Simonsen og gdr. Jens Brask. Også på Skovgård i Styding mødte jeg den sikre 


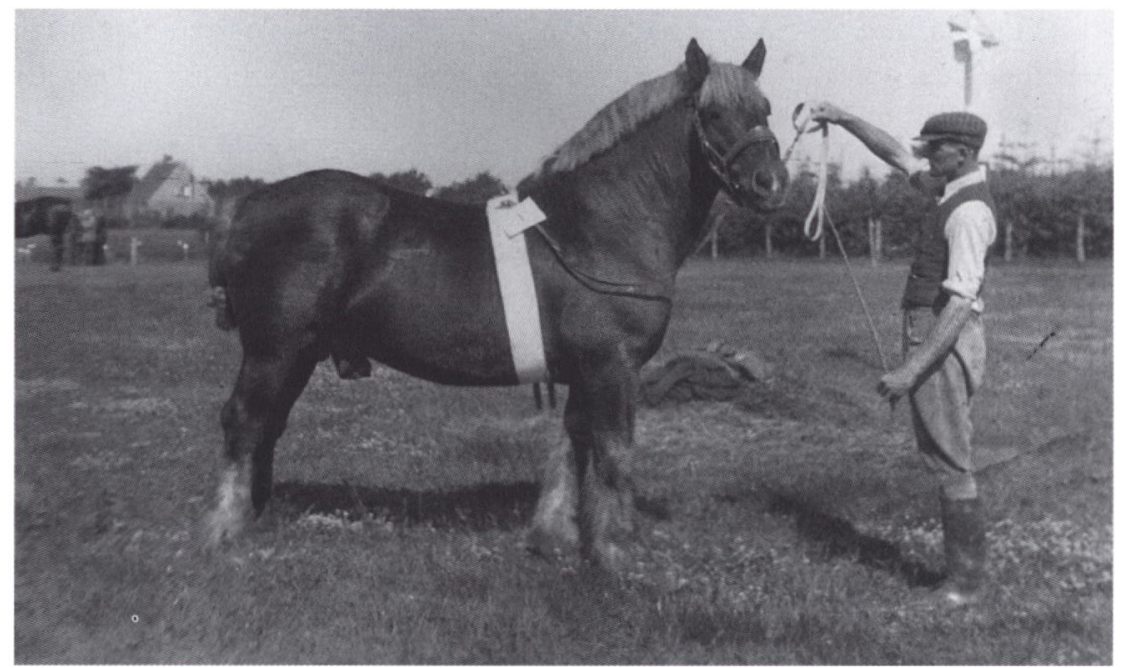

Fr. Rudbeck til dyrskue i Haderslev 1940. Foto i privateje.

overbevisning, at det var Venstre - og i hvert fald ikke Bondepartiet - som varetog landbrugets interesser bedst, og at partiets liberale holdning såvel $\mathrm{i}$ folkelig og national henseende ville gavne ikke kun Sønderjylland men hele landet.

$\mathrm{Da}$ jeg gennem nogle år havde været ret aktiv indenfor VU, fik jeg fra VU i Sønderjylland det tilbud at tage et ophold på den liberale skole Brejdablik i Vejen. Hans Skau fandt, at det var en god idé. Jeg fik orlov. Den 3. januar 1940 startede skolen under forstander Arthur Petersens ledelse. Og opholdet skuffede absolut ikke. Mange kendte politikere og højskolefolk gæstede skolen og holdt foredrag. Selv blev jeg som eneste sønderjyde tidligt indlagt til at holde et foredrag om nationalsocialismens fremkomst $i$ Tyskland og senere $i$ forbindelse med et besøg af VU fra Esbjerg fik jeg til opgave at tale om det nationale arbejde i Sønderjylland.

I begyndelsen af februar blev jeg indbudt til sammen med den radikale folketingskandidat, amtsskolekonsulent J. Dige, i Bække forsamlingshus at diskutere udstykningsspørgsmålet. Her var Venstres opfattelse, at vel skulle der fortsat udstykkes, men samtidig sporedes også en vis betænkelighed ved, at staten efterhånden fik rådighed over stadig mere jord.

Det må være dette møde, der et par uger senere fik Kolding Folkeblad til at henvende sig til mig, om jeg ville deltage som opponent ved et møde, kommunisterne ville arrangere i Vejen. Det var under Finlandskrigen, og det kunne blive en passende anledning til at starte en Finlandsindsamling. Egentlig skulle 
Aksel Larsen være kommet, men det blev partifællen, den senere trafikminister Alfred Jensen, som absolut ikke brød sig om de indlæg, en ung SdU'er fra Esbjerg og jeg tillod os at komme med. Vi fik kun ordet én gang, hvorefter han nærmest prøvede at tale forsamlingen ihjel. Vi måtte derfor benytte os af idelige afbrydelser, så stemningen i den ca. 150 mennesker store forsamling nærmede sig efterhånden kogepunktet. Det lykkedes dog at få vedtaget en resolution, der udtalte sympati med finnernes kamp, og der samledes ind til Finland. Det sidste dog under politibeskyttelse, da Alfred Jensen direkte opfordrede til at tage de indsamlede penge fra os. Men der indkom dog hele 48 kr. Brejdablikkerne var i den kommende tid ikke sarlig velsete blandt Vejens dengang mange kommunister. Efter mødet $i$ Vejen blev den møderakke, som kommunisterne havde planlagt over hele landet, kun fortsat med et enkelt møde. Det endte lige så kaotisk.

\section{Skæboneåret 1940}

Vinteren 1939-40 blev den første af de tre fimbulvintre, Danmark kom til at opleve. Der var koldt alle vegne. Heldigvis kunne vi takket være Skovgårds store skovareal nok sikre os det fornødne brændsel. Foråret var ved at nærme sig, og vi skulle have en bunke markarbejde til side. Jeg havde været i Haderslev den 8. april, og tilsyneladende åndede alt fred og ingen fare. Men så slog lynet ned. Ud på natten begyndte flyveriet, som vi egentlig ikke tænkte meget over. Der var ofte overflyvninger.

Men tidligt om morgenen blev Hans Skau ringet op af svigersønnen Hans Thulstrup i Haderslev, og fik beskeden at tyskerne var på vej. Kort tid efter kunne vi gennem telefonen høre skyderi fra Haderslev, og en dansk motorcykelpatrulje drønede forbi gården på vej mod nord, hvor man regnede med at skulle kæmpe imod tyskerne. Sognefogeden kom for at meddele en af vore folk, at der nu var mobiliseret, og at han derfor skulle melde sig på kasernen i Haderslev. Han kom dog hurtigt tilbage. Kampen var afblæst, Danmark havde kapituleret, og over kasernen vejede $\mathrm{i}$ de kommende fem år naziflaget.

Hvad tænkte vi i grunden denne 9. april, en af de første forårsdage i dette år? Først og fremmest, at nu kunne tyskerne vel finde på at sløjfe grænsen, den sidste af grænserne fra den forhadte Versaillestraktat. Så blev vi igen tyskere med alt hvad det ville indebære. Det beroligede noget $\mathrm{i}$ den officielle tyske proklamation at høre, at dansk integritet ville blive respekteret. Der blev ikke talt om grænsen. Alligevel gjorde vi os vore tanker.

For mig var det desuden et spørgsmål, om tyskerne ville respektere mit forholdsvis nyerhvervede danske statsborgerskab. De der ikke havde deres 
statsborgerskab i orden blev omgående indkaldt. Hans Skau var derfor heller ikke sikker, men nu kunne vi jo se, hvad der skete. Hvis tyskerne skulle finde på at jagte mig, kunne jeg holde mig lidt væk fra gården, være i mark eller skov eller hos venlige naboer. Skulle det gå så galt, kunne jeg også få en dækadresse. Det fremgår af en seddel i min lommebog for 1940 med adressen på fru Skaus søskende på Møn. Her kunne jeg tage over, og så skulle de nok sørge for, at jeg undgik tyskerne.

Den 10. maj kom en tysksindet medarbejder, vi havde, glædestrålende og fortalte os om de store tyske sejre under angrebet på Holland, Belgien og Frankrig. Han fattede vist ikke helt, at vi slet ikke kunne dele hans begejstring men tværtimod svarede ham, at Hitler nok ville sejre sig ihjel. Det kunne han ikke lide at høre. Han hørte nu til den fredelige slags, så vi følte os ikke truet.

Nærmest som en selvfølge forbød besættelsesmagten denne sommer, at der måtte holdes genforeningsfester. Det var $\mathrm{i}$ høj grad rygternes tid. Et gik ud på, at tyskerne ville benytte Versaillesdagen den 28. juni til at indlemme Nordslesvig og dermed flytte grænsen til Kongeåen. Det svarede ikke til Hitlers tidligere udtalelser om, at han intet grænsevisionskrav havde overfor Danmark, ligesom der i erklæringerne den 9. april var lovet sikring af dansk integritet. Men alt var muligt.

Usikkerheden oplevede jeg også, da jeg i juni 1940 sammen med en flok andre sønderjyder deltog i et Venstres Ungdoms formandsmøde i Odense. Det egentlige årlige landsstævne blev aflyst. Det gjorde et stærkt indtryk på os, at vi fra mange sider fik at vide, at rygtet nok lå nærmere sandheden, end vi selv troede. Man var derfor nærmest parat til at tage afsked med os.

$\mathrm{Da}$ jeg den 24. juni kom hjem fra Odense, gjorde jeg holdt hos nogle slægtninge, der boede i Slotsgade i Haderslev lige overfor den tyske Borgerforening. Jeg vidste, der havde været et stort tysk komsammen den 23., så de vidste sikkert noget. Jo, de havde da godt set hjemmetyskerne komme storskrydende til Borgerforeningen, men efter et par timer drog de noget slukørede hjem. Samme dag meddelte Nordschleswigsche Zeitung, at al flagning med tyske flag var forbudt, og vi fik desuden at vide, at de allerede udleverede flag skulle afleveres på kasernen i Haderslev. Berlin ønskede ingen vrøvl om dette lille stykke land. Så vi blev heller ikke tyskere denne gang.

Heller ikke vore egne nazister havde heldet med sig, da de i begyndelsen af december ville demonstrere deres magt i Haderslev og dér fik med dansk politi at gøre. Højskolehjemmet, hvor nazimødet skulle holdes, blev spærret af, efter at de truende med deres spader havde gennemført en march hertil. Jeg var netop i Haderslev tidligere på dagen, inden det egentlige "spadeslag« begyndte, men en telefonopringning senere oplyste os om det videre forløb, og hvordan mange Haderslevborgere havde undt disse tåber at blive kølet af. 


\section{Navneskiftet i DuG}

Da jeg nu boede i Hammelev sogn, var det naturligt at deltage i sognets liv. Men først og fremmest ønskede jeg at genoptage mit arbejde som tillidsmand for Det unge Grænseværn. Som følge af besættelsen den 9. april, var det vigtigt, at der i Nordslesvig fandtes en stærk national ungdomsorganisation. Det kom nærmest som et chock for mig, da DuG den 20 . april 1940 meddelte, at man havde besluttet at ændre organisationens navn til Dansk-Nordisk Ungdomsforbund. Først siden fik vi at vide, at dette navneskifte havde været drøftet internt i nogen tid, og at der heller ikke indenfor DuGs ledelse havde været enighed. At navneændringen kom så kort efter 9. april gjorde det ikke bedre. Jeg skrev til Peter Marcussen og gav i kraftige vendinger udtryk for mine følelser, samtidig med at jeg meddelte, at jeg ikke længere kunne være tillidsmand for organisationen.

I begyndelsen af juni holdtes der på Vojens Ungdomsskole et tillidsmandsmøde for hele Haderslev amt, og her gik bølgerne højt. Tilslutningen til navneskiftet var i hvert fald i denne kreds yderst begrænset. Personligt var jeg meget enig med dem, der følte det som et svigt i en tid, hvor vi netop i Sønderjylland fik noget at værne om, mens vi ikke følte os nær så overbeviste om den nordiske tankes bæredygtighed.

Det faldt da i sommeren 1940 i min lod at holde foredrag i Esbjerg om dette navneskifte. Jeg så nu noget mere nøgternt på den nye situation. Der blev jo fra tysk side bejlet kraftigt til de nordiske lande. Der fabuleredes om, at Norge, Sverige og Finland skulle danne en særlig skandinavisk blok, mens Danmark som følge af sin territoriale beliggenhed ønskedes fastere knyttet til kontinentet. Alene denne situation kunne nok forsvare et nærmere dansk-nordisk samarbejde. Det blev da også min konklusion: »Igennem en kraftig indsats til fremme af danskheden i Nord- og Sydslesvig at skabe et sikkert værn ikke kun for Danmark men også for det øvrige Norden«.

Ganske talende for den spændte situation, vi befandt os $i$, havde bladet Vestkysten meddelt, at foredraget ikke kunne refereres. Min holdning til denne sag førte til en længere brevveksling med Peter Marcussen, og nogen tid efter mødtes vi i Haderslev. Jeg prøvede at forstå navneskiftets nødvendighed, men var fremdeles ikke begejstret. Skulle navnet på et eller andet tidspunkt komme tyskerne på tværs, så jeg hellere, at det blev dem, der enten fremtvang et navneskifte, eller at organisationen blev opløst. Som bladet Hejmdal skrev: "Vi har $\mathrm{i}$ forvejen Foreningen Norden og andre organiserede rammer for nordisk samarbejde. Men vi havde kun ét Grænseværn, og det har vi mistet«. 


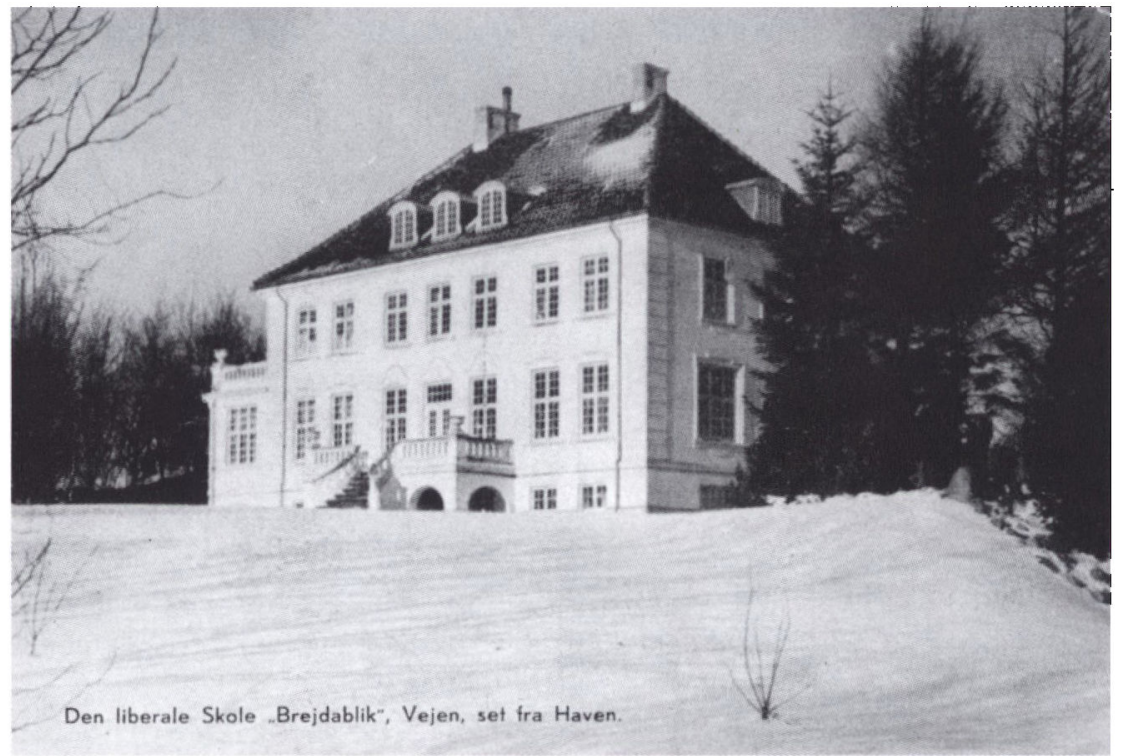

"Brejdablik" i vinteren 1940. Postkort i privateje.

Venstres Ungdom og dansk foreningsliv under besættelsen

Venstres Ungdom lagde beslag på stadig flere kræfter. Efter min hjemkomst fra Brejdablik valgtes jeg i marts 1940 til bestyrelsen for VU i Haderslev Østeramt og blev næstformand. Formand var gdr. Gunnar Midtgaard, Østergårds Mølle i Hoptrup. Foreningen var ikke særlig aktiv på dette tidspunkt. Dog havde det været store dage, da VU's landsorganisation i 1937 holdt sit landsstævne i Haderslev.

Såvel stævnet i Haderslev 1937 og landsstævnet i 1939 i Aarhus og endelig opholdet på Brejdablik gav mig nye impulser. I bestyrelsesarbejdet i den lokale forening havde jeg mulighed for at omsætte disse impulser i praktisk arbejde. Allerede i 1940 startede vi med et sommermøde i Christiansdal, hvor Simon From talte. I årene derefter fortsattes rækken af sommermøder på Vesterris, på Østergårds Mølle, i Sverdrup færgegård og igen i Christiansdal. Som talere brugtes i reglen lokale kræfter, folketingsmændene Simon From og Jørgen Gram, redaktør J. N. Nielsen, Dannevirke, forstander Hagelsø, Vojens. Ved et af møderne i 1943 talte VU's daværende landsformand Alfred Larsen. Møderne var stort set altid velbesøgt af såvel unge som ældre.

Mit engagement $i$ bestyrelsen førte til deltagelse $i$ adskillige møder $i$ den 
sønderjyske storkreds. Ofte var det såkaldte fortrolige møder, hvor politikere og redaktører gav en orientering om de aktuelle forhold.

Det var ellers rygternes tid, ikke mindst omkring begivenhederne den 9. april. Det var derfor interessant på VU’s landskursus i februar 1941 at høre en meget grundig orientering af tidligere minister dr. Oluf Krag. Han fremhævede, at her stod vi med de ulykkelige følger af Stauning-Munchs politik. Den havde lukket vore øjne for det, der skete ude omkring os. Det havde præget vor forsvarspolitik og Danmarks optræden i Folkeforbundet. Vi skulle ikke udfordre. Redaktør Jacob Kronikas og ritmester Hans Lundings advarsler blev henlagt, og da besættelsen kom, var kapitulationen derfor den eneste udvej.

I sommeren 1941 blev der startet noget, man kaldte wfrivillige danske arbejdslejre«. Vi fik sådan en lejr til Hammelev, hvor der arbejdedes med et afvandingsprojekt i Hindemade ned mod Haderslev Dam. En af disse lejres igangsættere var højskoleforstander Robert Stærmose fra Støvring, som vi en dag fik besøg af. Stærmose, der tilhørte Dansk-Samling, mente, at de gamle partier alt for emsigt affandt os med tyskernes krav. Der skulle vises helt anderledes håndfast optræden. Her var vi imidlertid slet ikke enige. Vel var modstandskampen begyndt, og vi hørte om sabotage. Men mange sønderjyder hyldede den opfattelse, at der næppe var grund til selv at forvolde alt for mange ødelæggelser. Snarere holdt man sig til salmebogens nr. 602 »Est Du modfalden kære ven«, hvor det siges:

Der er blandt folk et gammelt ord, hver djæevel har sin tid.

Men vist er det, tabt har enhver, som gik med Gud i strid.

Da denne salme blev sunget under en gudstjeneste i Haderslev, var det lige ved at koste stiftsprovst Flensmark embedet. Tyskerne forstod udmærket meningen.

I marts 1942 afløste jeg Gunnar Midtgaard som formand for VU i Haderslev. I min næstformandstid havde foreningen takket være de altid velbesøgte sommermøder fået et godt ry. Det sås også på medlemstallet, der fra ca. 150 steg til godt 200.

Allerede i efteråret 1940 blev der i Haderslev etableret et samarbejde mellem en række politiske og upolitiske ungdomsforeninger på grundlag af Dansk Ungdomssamvirke, som under ledelse af professor Hal Koch lagde op til et bredt folkeligt oplysningsarbejde til styrkelse af en dansk bevidsthed, og til passiv modstand mod de tyske besættere. Særlig aktive i dette arbejde var det lokale samvirkes formand dommer Sigurd Andresen og kommuneassistent, 
senere socialinspektør Olaf Christensen. Vi startede med på Christian Xs fødselsdag den 26. september at holde en kongefest, hvor jeg holdt en af talerne. Det blev en meget vellykket aften.

Samarbejdet fortsatte i de følgende år med en række store møder på Harmonien. Blandt talerne var redaktør Peter de Hemmer Gudme, som selv senere blev en af modstandskampens ofre, professor Hal Koch, general Gørtz og flere kendte politikere. Stort indtryk gjorde også en sangaften med Aksel Schiøtz, som jeg netop havde oplevet i København, hvor han spillede Farinelli i Det ny Teater. Stærkest husker jeg en aften i 1943 med Kaj Munk, som indledte med at sige, at han ikke ville holde tale, men kun mindes tre soldater, den danske soldat i 1864, soldaten den 9. april og så kong Christian. Derefter læste han sit skuespil "Niels Ebbesen«. Dansk Ungdomssamvirke var desuden stærkt engageret $i$ tilrettelæggelsen af festerne under Haderslev bys 600 års jubilæum i 1942. Det blev en meget fin og stort anlagt fest den 15. juni i amtsbanernes gamle remise ved Jomfrustien.

Den 23. marts 1943 var det folketingsvalg, hvor det i Sønderjylland især blev Danske Samfund, som stærkt opfordrede alle til at stemme på et dansk demokratisk parti. Det tyske mindretal opstillede ikke ved dette valg, da adskillige af deres vælgere var ved fronten som krigsfrivillige. Mindretallet fik så i stedet et tysk kontor i København med assessor Rudolf Stehr som leder. Man kunne derfor godt frygte, at en del af mindretallets stemmer ville gå til Frits Clausens danske naziparti eller til det efterhånden også tydeligt naziinficerede Bondeparti. Mens Bondepartiet kun fik 1,4 pct. af samtlige stemmer i Sønderjylland, fik nazisterne en beskeden fremgang fra 4,7 til 5,7 pct. Den i forhold til valget i 1939 betydeligt lavere valgdeltagelse på kun 79,5 pct. lod antyde, at hjemmetyskerne ikke havde deltaget i valget. Heller ikke Dansk Samling, som ellers slog stærkt på de nationale strenge, opnåede mere end 1,8 pct. Til gengæld kunne de gamle partier alle notere en fremgang. Egentlig skulle der også være afholdt kommunevalg. Det blev aflyst, men i maj gennemførtes det $\mathrm{i}$ hele det øvrige land. I Sønderjylland fortsatte de gamle kommunalog amtsråd til 1946.

Den 28. august 1943 holdt VU i Haderslev høstfest. Både folketingsmand Simon From og redaktør Aksel Søchting kom med forblommede vendinger om, at noget var nært forestående. Hvad det var, erfarede vi tidligt søndag morgen den 29. august. Scavenius-regeringen og Rigsdagen var ophørt at fungere, og der var erklæret undtagelsestilstand. De onde tider blev nu for alvor onde.

Allerede i vinteren 1939-40 havde vi med forstelærer Chr. Lorenzen, Styding som leder startet en studiekreds over emnet "Grænselære« på grundlag af Claus Eskildsens bog »Dansk Grænselære«. Denne studiekreds samlede en 15- 
20 deltagere og fortsatte flere år frem med skiftende emner af såvel samfundspolitisk og storpolitisk indhold. Møderne holdtes på skift i hjemmene, hvor husmødrene ofte forbavsede os med et trods rationering veldækket kaffebord. Den ene ville nødig være ringere end den anden. Også Hammelev mandskor havde jeg megen glæde af at være med i, til koncerter i omegnen eller i Hammelev kirke.

Da vi i 1940 havde fået en afdeling af Danske Samfund i sognet med den nationalt sindede mejeribestyrer Mathiesen som formand, fik vi et bredere grundlag for større danske arrangementer. I vinteren 1940-41 var jeg således med til at tilrettelægge et møde med forstander Hans Lund. Det samlede fuldt hus, og efter foredraget besluttede Mathiesen, at også andre skulle have ordet. Han havde sit ståsted i Indre Mission, men forstod det folkelige arbejdes værdi.

Desuden lå det ham meget på sinde at få unge og yngre aktiveret. Det blev derfor nogle af de unge, der temmelig uforberedt skulle fremsatte deres meninger om en række emner, Mathiesen forud havde valgt. Hans Lund var meget begejstret for denne aften, hvor mange gode synspunkter kom til udtryk. Hans Skau havde samme syn, at det ikke altid skulle være de ældre, der førte ordet.

Da han nu igen blev bedt om at tale ved høstfesten i sommeren 1942 mente han, "at nu er tiden inde til, at I unge får ordet«. Så jeg måtte holde høsttalen, og notaterne til denne tale har jeg stadig liggende. Dem kunne jeg genbruge, da jeg i 1970 i anledning af 50-året for afstemningen i 1920 blev bedt om at tale i Hammelev.

\section{Kontrolassistent i Hoptrup}

Jeg havde valgt at indrette min tilværelse på, hvad jeg vil kalde tre søjler landbruget, det nationale og det politiske. Heraf måtte landbruget blive det bærende. Da Skovgårdopholdet sluttede til 1. november 1942, var jeg derfor mest interesseret $\mathrm{i}$ at fortsætte på en anden større gård. Men først søgte jeg stillingen som rejsesekretær i Venstres Ungdom. Dog var jeg ikke sikker på, om der her lå en blivende opgave. Heldigvis blev det da en anden, der fik den.

Da det imidlertid syntes vanskeligt at finde en passende forvalterplads, valgte jeg i stedet noget helt andet. Jeg sogte og fik stillingen som kontrolassistent i Hoptrup og omegns kontrolforening. Uddannelsen havde jeg fra Næsgaard. Det var en helt ny tilværelse, også en form for rejseliv, med hele tiden skiftende ophold.

Den række af gårde i Hoptrup, Djernæs, Sønderballe og Genner strand jeg betjente som kontrolassistent, var af vidt forskellig observans. Der var afgjort 


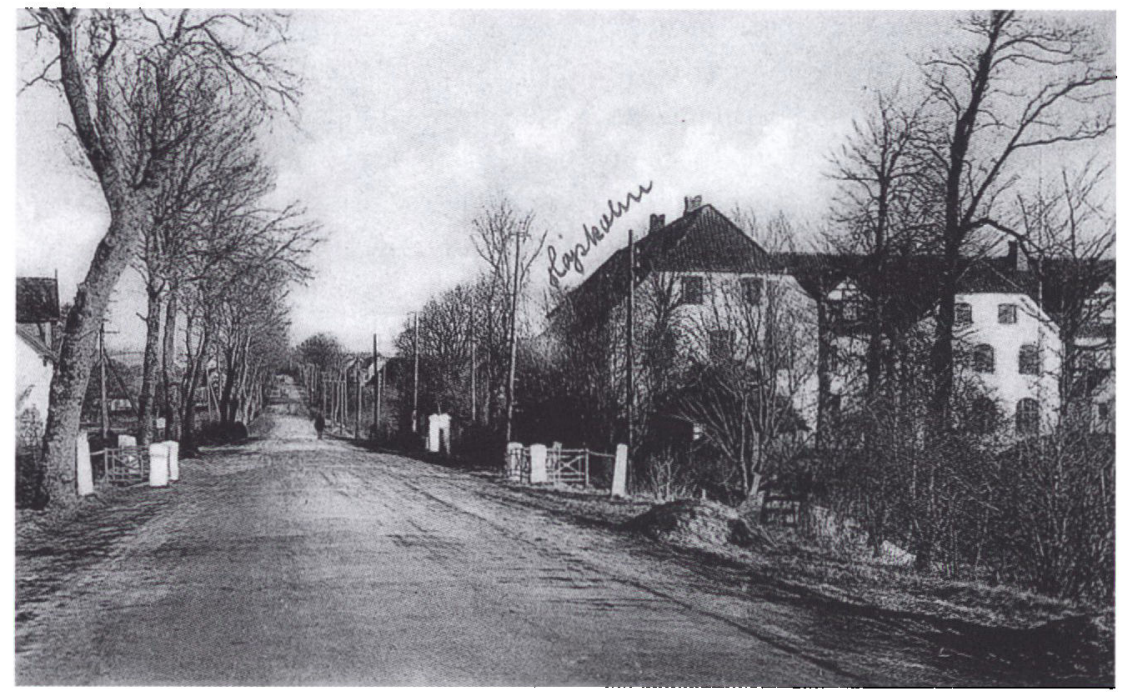

Fra Hoptrup i 1930'erne. Postkort i Institut for Senderjysk Lokalhistorie.

danske, nogle lunkne, en enkelt hjemmetysker og en fanatisk nazist. Den sidste var tydeligt en af Sønderjyllands triste skæbner. På hans gård holdtes i 1920 afstemningsfesten i glæden over, at man kom til Danmark. Hans børn bar gode danske navne som Thyra og Uffe. Men så kom landbrugskrisen, som blev særdeles hård for gården. Han fulgte LS, fik måske også støtte fra Vogelgesang. I hvert fald gik hans børn nu i tysk skole, som hans kone var i bestyrelsen for. Selv var han fanatisk nazist. Frits Clausens og Hitlers billeder kom til at hænge, hvor for danske kongebilleder havde deres plads. Naturligvis var jeg ikke på bølgelængde med denne familie. Da han en dag ligefrem overfusede mig på grund af min holdning, afstod jeg fra at komme dér mere. Hans skæbne efter besættelsen blev da heller ikke særlig morsom, selv om han hørte til de små fisk.

Jeg befandt mig godt på denne egn. Flere af de danske familier, jeg kom til, var meget bevidste i deres danske holdning. Det krævede lidt af en omstilling at komme fra besøg $i$ et sådant hjem til en ganske vist moderat hjemmetysker. Hoptrup højskole og forsamlingshuset var de steder, hvor vi samledes. En studiekreds ledet af lærer Martha Uldall Jessen - ved befrielsen kendt som "Revolver-Martha « - deltog jeg også i. Dog flyttede jeg fra egnen, inden denne studiekreds udviklede sig til en egentlig modstandsgruppe.

I stigende grad skete der overflyvninger af allierede bombemaskiner på vej mod Tyskland. En nat kort før jeg rejste fra Skovgård tømte et allieret fly hele sin ladning af brandpile omkring gården. Enkelte faldt kun få meter fra de 
stråtækte bygninger, andre mellem græssende kreaturer og følhopper. Men ganske mirakuløst skete der intet. Bombekratere efter bomber fra fly udsat for tyske jagerangreb fandtes mange steder. I Hoptrup var hovedvejen i langere tid spærret af frygt for at nogle bomber der var faldet nær op ad Hoptrup højskole skulle eksplodere. En sen eftermiddag, da jeg var på vej mod Hoptrup, drønede en eskadre af britiske Moskito-fly lavt ind over markerne. Det viste sig at være de maskiner, der i København havde været med ved bombningen af Burmeister \& Wain.

Selv om arbejdet som kontrolassistent var ganske interessant, var køer, fedtprocenter, mælkemængde og foderplaner ikke det, der i længden optog mig mest. Så efter et år opgav jeg denne bestilling.

\section{Store Tønde}

Til november 1943 søgte jeg igen flere forvalterpladser, og det endte med, at jeg fik plads hos en anden kendt sønderjysk landmand, forpagter Hans Linnet på Store Tønde i Jejsing. Hans Linnet var storforpagter. Selv boede han ikke på gården, men i Møgeltønder og kørte så rundt og tilså sine gårde. Der var i reglen stor opstandelse, når forpagteren kom på inspektion.

Til gården hørte et mejeri, og der hentedes mælk fra flere omliggende gårde. Mejeribestyrerfamilien fik jeg et særdeles godt forhold til. Der var også nogle gode aftener i Hostrup præstegård, men ellers følte jeg mig lidt på en yderpost. Der var hjemmetyskere rundt omkring os, og om søndagen så vi dem i deres grønne uniformer, klar til søndagseksercits. De hyttede sig hjemme og var rede til i givet fald at holde os danske i skak under en måske kommende invasion.

Hen på vinteren kom jeg til skade med en arm, og måtte for en rum tid stoppe alt fysisk arbejde. Jeg var derfor heller ikke ked af til maj at rejse fra Store Tønde. Forinden var jeg en kort tid indlagt på Tønder sygehus, og mærkede her lidt af stemningen i det ret blandede område. Straks da jeg var blevet indlagt, gjorde et par sengekammerater mig opmærksom på, at det var klogt at være forsigtig med, hvad man sagde. Et par af stuefællerne stolede man ikke helt på. Desuden var der tyske vagtposter på gangene, som holdt opsyn med en nedstyrtet allieret pilot.

Sygdomsperioden betød, at jeg kunne samle mig om den anden interesse, den politiske. Jeg begyndte at skrive artikler til VU's medlemsblad Dansk Folkestyre om såvel politikere og nationale emner. 1943 var hundredåret for de store Skamlingsbankemøder. Jeg henvendte mig til Troels Fink, dengang docent ved universitetet i Århus og bad ham skrive en artikel om disse begivenheder. Det var han nu ikke meget for, men opfordrede mig i stedet til selv at 
skrive. Det blev så resultatet, og på den måde blev Troels Fink måske igangsætteren til det langvarige nationale skriveri, jeg siden kastede mig over. Det nationale blev den sidste side af mine gøremål.

\section{Det nationale}

I Dansk Ungdomssamvirkes regie deltog jeg i juli 1944 i et kursus på Grænsehjemmet $\mathrm{i}$ Kollund, hvor vi diskuterede den aktuelle situation og fremtiden. Her fik vi den 20. juli meddelelsen om attentatet på Hitler. Vi var ellers en starkt blandet flok i forskellige aldre og fra alle egne af landet og desuden af vidt forskellig observans. Der blev holdt en række fremragende foredrag.

En foredragsholder skal fremhæves, nemlig rektor Bernhard Hansen fra Duborgskolen. Han talte om "Dagens gerning". Vi havde jo ikke siden krigens udbrud hørt meget til Sydslesvig. Vel følte vi med dem, da en bomberegn over Flensborg den 19. maj 1943 udslettede en dansk børnehave og 14 børn og to pædagoger blev bombernes ofre. Vi hørte om de faldne danske og glædede os over, at vi i Nordslesvig var undsluppet krigens rædsler.

Hvad der iøvrigt rørte sig syd for grænsen, kunne der af gode grunde intet siges om. Derfor var meningerne om Sydslesvigs fremtid også højst delte, hvilket nok især kom frem, da lærer Martin Mortensen fra Sønderborg talte varmt om, hvilke opgaver der efter krigen ville vente os omkring Sydslesvig. Han lagde ikke skjul på, at tiden da ville vare inde til at kræve Sydslesvig tilbage, og at man i Sydslesvig ventede det af Danmark. En af de få, der forstod denne tale og også stillede sig positivt, var Erik Haunstrup Clemmensen, der som Heimdal-student ofte havde været i Sydslesvig. Senere mødte jeg ham igen indenfor et aktivt grænselandsarbejde og sidst som Grænseforeningens formand.

Den 19. september 1944 var jeg i Haderslev, da der pludselig blev luftalarm. Først senere erfarede vi, at tyskerne overalt benyttede luftalarmen til at få folk væk fra gaderne, mens de afvæbnede og internerede det danske politi. Det gav øget usikkerhed. Da Hans Skau således i november 1944 kom ud for et overfald på vej hjem fra Haderslev, måtte pågribelsen af den skyldige vente til efter 5. maj 1945.

\section{Mod krigens slutning}

Krigens gang blev fulgt nøje. De gamle kort viser, hvordan vi dagligt markerede tyskernes »taktiske tilbagetog«. Samtidig så vi, hvordan unge fra hjemmety- 
ske hjem nærmest blev tvunget til at melde sig som frivillige. To unge, der begge havde været karle på Skovgård, blev således krigens ofre. Da jeg senere læste deres navne i Mindelunden på Knivsbjerg, kunne jeg ikke lade være med at tænke på, om vi ikke også selv havde skyld i disse unge menneskers død? Hvor ofte havde vi ikke stiklet til dem og spurgt, hvornår de skulle ned og forsvare deres Vaterland. Mange var ude for et stærkt pres og måtte efter krigen gennem straf og fængsel. Det var meget forkert. De gjorde kun, hvad de følte eller blev tvunget til at tro var deres pligt.

Anderledes med dem, man mødte om søndagen i den grønne uniform som "Zeitfreiwillige«. Dem så jeg en del til ude på Tønderegnen. Dem skyldte vi ingen pardon. De hyttede sig herhjemme, men rede til i givet fald at holde danskerne i skak under en måske kommende allieret invasion.

Sabotage og Schalburgtage hørte til dagens orden. I Haderslev gik det ud over Danevirkes trykkeri og Hundevadts nye varehus, som tyskerne sprængte.

Efter uheldet med armen og operationen måtte jeg igen til november 1944 begynde som kontrolassistent, nu i Rangstrup. Igen var det en meget blandet kreds af familier og dermed gårde, jeg kom rundt i. Det var en solid dansk egn. Der var ingen hjemmetyskere imellem, men en enkelt fuldblods nazist. Det berørte os alle stærkt, da vi hørte om henrettelsen af dr. Jørgen Teilmann i Overjerstal. Jeg kom tit forbi skomager Wilh. Hagner, som sammen med stedets tyske lærer havde anmeldt lægen for sabotage og våbenbesiddelse, og var ikke altid helt tryg, især når min mappe var fyldt med illegale forsendelser, der skulle postes et eller andet sted. Skomagerens tyskhed var kendt. Han fik også sin straf, først dødsstraf siden livsvarigt fængsel, indtil han blev benådet og udvist.

Måske skyldtes det mine talrige flytninger i krigens sidste år, at jeg aldrig fik noget direkte med modstandsbevægelsen at gøre. De studiekredse, jeg havde deltaget i i Øsby og Hoptrup, udviklede sig siden til aktive modstandsgrupper. Men det var efter jeg var rejst. Dog modtog jeg efterhånden forsendelser af illegale blade, som jeg pligtskyldigst sørgede for at distribuere videre. Da jeg $\mathrm{i}$ vinteren 1944-45 havde postadresse under Bevtoft, kunne det vakke uro, når disse pakker ikke altid kom i velemballeret stand, og det tydede på at de havde været åbnet. Postmesteren i Bevtoft gik for at være nazist og tyskvenlig. Han blev da også efter 5. maj sat fra bestillingen.

I den sidste krigsvinter havde jeg glæde af at føre samtaler med gdr. Søren Ratzer i Rangstrup. Han var amtsrådsmedlem for Venstre, formand for dagbladet Dannevirke og havde andre offentlige gøremål, et menneske, der var stærkt optaget af tidens strømninger. Han var Flensborgmand som mange på egnen, hvilket han aldrig lagde skjul på. Ratzer var åndeligt en stærk personlighed, men fysisk var han svag. Han døde den 27. april 1945. 
Hans begravelse fra Agerskov kirke kunne minde om en høvdingebegravelse. Det var en af de stoute og stærke sønderjyder, der den dag blev fulgt til graven. Endnu kan jeg se for mig den tyske soldat, der var kommet ind i kirken og andægtigt fulgte sørgehøjtideligheden. Hvem han var, ved vi ikke, men måske hørte han til de tyskere, der selv var klar over, hvilke forfærdelige ulykker hans land havde forårsaget. Søren Ratzer ville nok have forstået ham. Vi andre viste ham måske en for kold skulder.

Agerskov sogn var et stærkt dansk sogn, hvor der fandtes mange Sydslesvigog især Flensborg-engagerede mennesker. Jeg mødte her en række familier, hvor jeg altid følte mig hjemme: Søren Knudsen i Galsted, Andreas Appel i Rangstrup, Chr. Bossen i Fårhus, alle folk med stærke meninger og først og fremmest danske.

Her i krigens sidste fase mærkedes i stigende grad den tyske nervøsitet. Der blev gravet pansergrave, og der blev anlagt store kanonstillinger. De tyske soldater var præget af en nederlagsstemning, og talte man en sjælden gang med en tysk soldat eller officer, sporedes en frygt for fremtiden og ikke mindst tanken om, hvordan det gik med familien derhjemme, om den overhovedet havde overlevet denne frygtelige tid. De allieredes fly blev stadig mere nærgående og stadig større allierede flyformationer sås på himlen på vej til deres ødelæggelsestogter over Tyskland. Også på de hjemlige veje kunne det blive nødvendigt at søge dækning, når allierede fly næsten helt nede over hækkene fløj hen over os. Målet var så Skrydstrup, hvor man snart efter kunne se røgskyer stige op. Så vidste man, at nu var der igen tyndet ud i tyskernes beredskab.

At krigen rykkede stadig nærmere kunne konstateres gennem den fjerne rumlen fra kanonild og de tiltagende daglige overflyvninger. Uvilkårligt måtte jeg sende en tanke til Berlin, som var blevet frontby. Jeg havde stadig slægtninge dernede. Ville de overleve? Hvor meget af den by, jeg engang havde kendt, ville være tilbage, når det hele var forbi. I Haderslev passerede de hvide busser med danske og norske fanger fra koncentrationslejrene. Det var strengt at overvære ikke mindst ved tanken om, at ens egen far var død i en KZ-lejr.

VU's virksomhed blev efterhånden indskrænket. Da jeg rejste til Tønder, havde jeg opgivet formandspladsen i Haderslev, men jeg fortsatte som studiekredssekretær. Det kom som et chok for os, da VU's kasserer Evald Carlsen i december 1944, myrdedes af tyskerne. I foråret 1945 blev VU's kontor i København besat, og vi fik besked om at "gå stille med døren«. Ingen kunne jo vide, om et beslaglagt adressemateriale ville blive udnyttet på en for os ubehagelig måde. Da Hans Skau i denne sidste krigsvinter ikke havde fået nogen forvalter, og da min forlovede nu var i huset på Skovgård, kunne jeg godt forene det nyttige med det behagelige. I weekenden passede jeg landbruget på Skovgård, og de øvrige dage var jeg i Rangstrup. I de sidste måneder var det 
dog praktisk talt ikke muligt at overholde terminerne for kontrolbesøg. Der var jo fyldt med soldater og tyske flygtninge overalt, så da var jeg mest på Skovgård, hvor jeg tog mig af hele forårsarbejdet.

Alt imens gravede tyskerne pansergrave og huller ved vejene til geværskytter, der skulle standse en ventet allieret invasion. I min lommebog fra 1945 kan jeg dag for dag følge krigens gang. Endnu var det spørgsmålet, om russerne eller briterne ville komme først til den danske grænse. Efterhånden stod det klart, at Montgomerys tropper nu var stærkt på vej mod nord. Vi hørte dagligt radioen fra Sverige og England. At der ikke var langt igen, stod klart. Alligevel så det betænkeligt ud, da vi den 4. maj om eftermiddagen fik besked om, at vi skulle være rede til øjeblikkelig evakuering. General Lindemann ville kæmpe til det sidste, og derfor skulle hele området til en linie op mod Gjels å rømmes for civilister.

$\mathrm{Da}$ jeg tog hen til mit logi for at hente mine personlige papirer, kom budskabet fra London, at Tyskland havde kapituleret i Danmark.

Vi kunne ånde lettet op, og rive mørklægningsgardinerne ned. Den sidste rest rigtig kaffe kom frem, og lysene tændtes igen, efter at de havde været slukket i 5 lange år. Næste morgen kunne vi sammen hejse Dannebrog over et frit Danmark.

\section{Efterkrigstid - gårdmand i Gabøl}

Tiden efter befrielsen blev på mange måder skelsættende. Først oplevede vi befrielsesglæden. Til gengæld havde vi så fået flygtningene, hvis skæbne var alt andet end misundelsesværdig. Den 7. maj oplevede jeg de britiske troppers ankomst til Haderslev og de jublende menneskemasser, der fyldte gaderne og nærmest var ved at storme de britiske tanks, hvis mandskab rundhåndet uddelte cigaretter og chokolade.

Sommeren 1945 blev i øvrigt præget af de store frihedsfester. Den 24. juni var vi til det af Region III arrangerede kæmpemøde på Skamling med ca. 100.000 deltagere.

I 1943 var jeg blevet forlovet med Anne Marie Lei fra Harkærgård i Fredsted. Siden 1944 havde hun været i huset på Skovgård. Efter et par forlovelsesår var det på tide at blive gift. Da vi begge var indstillet på en fortsat landbotilværelse gjaldt det om at finde en passende landbrugsejendom. Hans Skau lovede mig økonomisk støtte, og vi undersøgte flere muligheder. Resultatet blev, at vi købte en gård i Gabøl på godt 15 ha. Det var måske ikke den bedste ejendom. Den var i nogle år blevet drevet sammen med en nabogård, og det havde sat sine spor. Der var hverken besætning eller redskaber, og 
bygningerne var heller ikke i den bedste forfatning. Men prisen var rimelig, og derfor slog vi til. Vi holdt nu bryllup, og den 1. juli 1945 overtog vi gården.

Det var lidt af en omstilling nu selv at skulle klare alt dagligt arbejde. Først og fremmest gjaldt det om at få skik på gården. Hans Skaus svigersøn, kreaturhandler Hans Thulstrup i Haderslev hjalp med at skaffe både køer og ungkvæg. En grisehandler fra egnen udstationerede nogle grisesøer hos mig. Fra hvert kuld grise tilfaldt der mig nogle stykker. Dermed blev der efterhånden også en grisebesætning. Med hensyn til heste måtte jeg låne mig frem. En hest fik jeg som lån fra Fredsted, mens min nabo Jørgen Gram på rimelige vilkår hjalp mig til en følhoppe. På en landboauktion købte jeg flere maskiner, jeg fik anskaffet tærskeværk og kværn, og efterhånden begyndte det at ligne noget. Også selve beboelsen trængte hårdt til istandsættelse. Det hele var trods alt mere forfaldent, end vi under de første besøg havde bemærket. Vi havde gåpåmod og med lidt fornuftigt håndelag og diverse armkræfter fik vi os efterhånden ganske fornuftigt indrettet. Også et stråtag på en af længerne måtte have en omgang, og laden fik en gang tjære. Så kunne vi efterhånden også være bygningerne bekendt.

Der skulle hentes tørv. Brændselsspørgsmålet havde vi aldrig beskæftiget os med på Skovgård, hvor der var træ nok. Med hestevogn hentede jeg tørv ved Rangstrup. Det var først det følgende år, man på landet kunne købe stenkul. Imidlertid havde vi flinke naboer, som gerne gav en håndsrækning. I det hele taget befandt vi os godt i Gabøl. Man kom hinanden ved, og som nybegynder $i$ en noget forsømt gård var det dejligt at mærke, hvor hurtigt vi faldt ind $i$ landsbyfællesskabet.

\section{Venstre-politik efter Befrielsen}

Ved siden af de daglige gøremål på gården havde jeg stadig forbindelse med VU. Jeg fungerede som en slags amtssekretær for de sønderjyske VU-foreninger og var studiekredssekretær. Jeg fik til opgave at holde et par VU-foreninger i Bylderup-Bov og i Løgumkloster over dåben. I det følgende år oprettedes også en VU-forening for Nustrup sogn. Antallet af VU-foreninger steg med ialt 12, ligesom der oprettedes flere nye studiekredse. Samtidig startede min virksomhed som skribent til VU's blad "Dansk Folkestyre«, hvor det nu i høj grad blev de grænsepolitiske spørgsmål jeg kommenterede.

I september deltog jeg i VU's landsstævne i Odense, der selvsagt var præget af efterkrigsstemningen. Det faldt i min lod at redigere det afsnit i Landsmødeudtalelsen, der berørte Sydslesvig, og hvor det siges: "Vore sydslesvigske landsmænd har krav på, at det danske folk gør, hvad det formår for at stå dem bi 


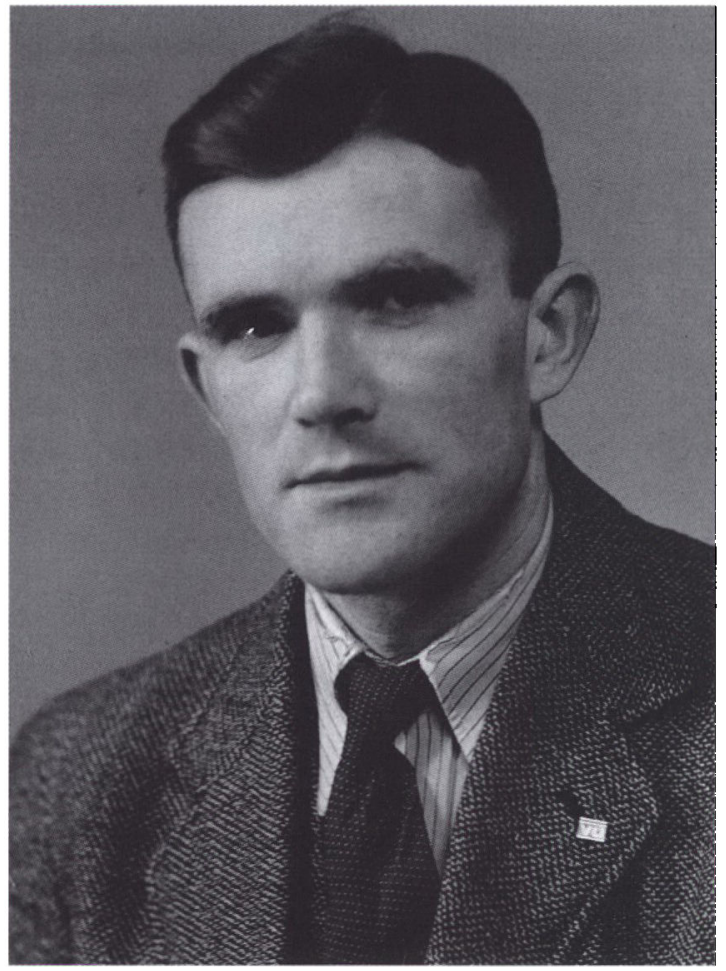

Frederik Rudbeck med $V U$-emblem $i$ knaphullet. Foto 1943. Privateje.

i den nuværende situation, hvor nød, sult og kulde banker på deres dør. Vor grænse skal fremtidig som førhen hvile på den nationale selvbestemmelsesrets grund. Danmark bør støtte sydslesvigernes bestræbelser for frigørelse fra tysk overhøjhed, og vi opfordrer regering og rigsdag til at optage forhandlinger med sydslesvigerne og sammen med dem frembære de fælles ønsker for vore alliereder.

I november 1945 havde vi folketingsvalg, der førte til dannelsen af Venstreregeringen under Knud Kristensen. Det betød også Christmas Møllers afgang som udenrigsminister. Vel havde han indlagt sig store fortjenester under besættelsen. Dog mærkede man i Sønderjylland ofte en vis afstandtagen fra hans opfordringer til øget modstand. Hans holdning til Sydslesvig følte mange som unødig hård, og hans Englandsaftale om dansk landbrugseksport gjorde ham ikke ligefrem afholdt blandt landbrugets folk. Som nabo til folketingsmand Jørgen Gram blev der ofte lejlighed til værdifulde samtaler om politiske og nationale forhold. Sydslesvigspørgsmålet rykkede i forgrunden, ikke mindst efter at Knud Kristensen på grundlovsmødet i Toftlund 1946 sluttede sin tale 
med en omskrivning af et par linier $i$ en af vore nationale sange "Sydslesvigs land genvundet, det er kampens mål«.

Imidlertid fulgte vi også de lokale begivenheder. I november 1945 startede vi en studiekreds i Gabøl. VU-foreningen i Nustrup, som jeg blev formand for, stillede andre krav. Vel blev det aldrig nogen helt stor forening, men den var der, og der blev holdt møder i samarbejde med den lokale Venstreforening. Foreningen blev siden udvidet til også at omfatte Vojens og nogle andre sogne. Hertil kom den lokale ungdomsforening i Nustrup, hvor jeg en tid blev medlem af bestyrelsen. Også Sydslesvigsk Udvalg lod høre fra sig. Vi fik et lokaludvalg i Nustrup sogn, og jeg deltog i et fællesmøde i Aabenraa, uden at jeg egentlig fik stort med direkte grænselandsarbejde at gøre. Det var der ikke rigtig tid til.

Hvor delte meningerne i Sønderjylland kunne være fik vi et tydeligt indtryk af under afstemningsfesten 1946 i Nustrup forsamlingshus. Her talte pastor Aage Møller tidl. Rønshoved, som ud fra sin mytologiske fortolkning fastslog vor ubetingede ret til Sydslesvig. Her måtte Jørgen Gram tage klart afstand. Vi måtte holde os til selvbestemmelsesretten og sikre den. Med vold kunne vi ikke kræve Sydslesvig tilbage.

Det blev en travl tid med mange møder af ofte politisk karakter, hvor jeg kom til at duellere med adskillige politikere. På landsstævnet 1946 kom Sydslesvig igen til at indtage en fremtrædende plads. I udtalelsen gik man nu et skridt videre ved at sige: "Den hjemmehørende befolkning alene skal til sin tid afgøre landsdelens fremtidige skæbne. For indtil da at sikre den danske folkegruppes rettigheder bør Sydslesvig udskilles fra det administrative fællesskab med Holsten og stilles under De forenede Nationers overhøjhed «.

Jeg blev medlem af et særligt Sydslesvigudvalg, som bl.a. fik til opgave at bearbejde en brochure om grænselandsforholdene. Her foreslog jeg et særligt Sydslesvigkontor, underlagt enten stats- eller udenrigsministeriet, ligesom jeg $i$ en artikel opfordrede til en bedre koordinering mellem sydslesvigernes ønsker og dansk Sydslesvigpolitik. Desuden slog jeg til lyd for en åbning af grænsen for unge sydslesvigere, der onskede en videregående uddannelse enten på højere skoler (læreanstalter) eller indenfor erhvervslivet. Endelig fik jeg VU til at overtage et fadderskab for den danske ungdomsforening i Frederiksstad, en forbindelse som fik stor betydning for flere unge dernede, der siden kom frem $i$ ledende stillinger indenfor det dansk arbejde i Sydslesvig.

Et højdepunkt i året 1946 var Christian X.s sidste Sønderjyllandsfærd. Kongen havde hvert år siden 1920 - kun besættelsesårene undtaget - aflagt besøg i den genforenede landsdel. Det var betagende at opleve den gamle konges gensyn med sønderjyderne. Jeg overværede kongens besøg i Haderslev. 

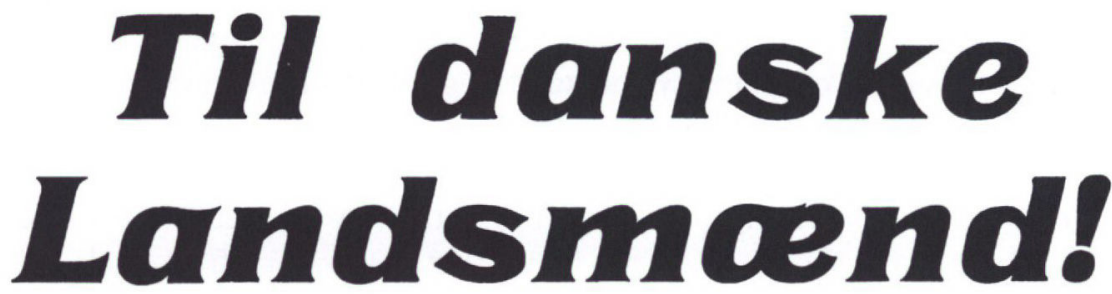

Da den politiske Udvikling i Sydslesvig i stigende Grad har vist, at den danske Bevægelse ikke vil faa fri og uhindret kulturel og politisk Udviklingsmulighed under det slesvig-holstenske Styre, ønsker vi undertegnede Mænd og Kvinder fra Nordslesvig at udtale:

1. Det danske Staasted i Spørgsmaalet Sydslesvig er den nationale Selvbestemmelsesret. Naar den danske Regering og Rigsdag har anerkendt den sydslesvigske Befolknings "naturlige Selvbestemmelsesret“, maa en simpel Konsekvens heraf være, at Danmark søger at sikre Sydslesvigernes Udøvelse af denne Ret ved at faa indføjet en Løfteparagraf $i$ den kommende Fredstraktat om Ret til en senere Afstemning om Landsdelens statslige Tilhørsiorhold.

2. For at sikre en fri folkelig Udvikling som Grundlag for den nationale Selvbestemmelse bør Sydslesvig sikres et eget Styre og dermed frigøres for holstensk Administration og Indilydelse, saaledes at der gives den hjemmehørende Befolkning fuld politisk og kulturel Frihed.

3. Med mindre Sydslesvig faar en administrativ Særstilling, vil det være umuligt at fjerne den ogsaa af den danske Regering og Rigsdag paapegede Fare, som Flygtningenes varige Forbliven i Sydslesvig betyder for Landsdelen dernede og for Danmark.

Den sydslesvigske Befolkning har allerede over for de allierede Stormagter rejst Kravet om Ret til en senere Afstemning, om administrativ Adskillelse fra Holsten og om Fjernelse af Flygtningene som et fremmed Folkeelement.

Muligheden for at opnaa dette foreligger ved Fredsslutningen, men næppe paa et senere Tidspunkt.

Derfor opfordrer vi det danske Folk til at give Sydslesvigerne en ærlig Chance for den folkelige Udvikling ved at paalægge Regering og Rigsdag af al Magt at arbejde for Gennemførelsen af ovenstaaende Krav, der tillige vil yde Sydslesvigerne et retsligt Grundlag for deres folkelige Kamp og Maal.

Sydslesvig-sagen var »det brandende spørgsmåk $i$ de forste efterkrigsår. Dette trykte opråb til stotte for en administrativ sarstilling for Sydslesvig og en kommende folkeafstemning blev udsendt $i$ Nordslesvig den 6. oktober 1947. Flyvebladet var underskrevet af 600 mand og kvinder over hele landsdelen. Fr. Rudbecks arkiv P 357-12. 
Imidlertid var den indrepolitiske situation jo langt fra fredelig. Der var stadig stærke spændinger mellem Venstre og Konservative navnlig så længe Christmas Møller var de konservatives leder. Hvor stærke modsætningerne kunne være, fik vi et klart eksempel på, da vi i foråret 1946 holdt afslutning på studiekredsen i Nustrup sogn. Vi havde bedt 5 partier om at lade sig repræsentere, og heriblandt vor ellers flinke sognerådsformand, gårdejer Jens Hansen, Nustrup, der samtidig var konservativ folketingskandidat. Han havde imidlertid valgt at bede folketingsmedlem Karl Olsen fra Kolding om at være sig behjælpelig.

Det viste sig at være mindre godt. I forvejen kendte jeg "Knalde-Karl's" arrogance, og vidste, at han var en dreven debattør. Så ingen mødte uforberedt. Nustrupbønderne var Venstrefolk, og de forstod at tage ham. Jeg fik siden at vide, at Karl Olsen absolut ikke havde været glad for denne aften.

Imidlertid stod det mig klart, at jeg ikke i længden magtede at klare gården i Gabøl. De store byrder fra de mange nyanskaffelser og vedligeholdelsesarbejder på de forsømte bygninger og de udsultede marker betød, at det var bedre at få solgt og måske finde noget andet. Det lykkedes uden tab, og 1. marts 1947 rejste vi fra gården.

\section{I arbejde for Sydslesvig}

Snart dukkede noget helt andet op. Under et besøg hos gårdejer Iver Hansen Østergård sen. i Gabøl, en mand med betydelig indflydelse og medlem af et utal af bestyrelser, spurgte han direkte, om jeg ikke kunne tænke mig at komme til at arbejde for Sydslesvig. Han kendte mine Sydslesvigforedrag og artikler. Også Jørgen Gram støttede tanken. Efter denne samtale optog jeg kontakt med gdr. Oluf Fink, der var formand for Haderslev Vesteramts Grænseforening, men han mente ikke at kunne pege på noget i selve Sydslesvig. I. H. Østergård kom så ind på, at han som medlem af De samvirkende danske Svineslagterier skulle være med til at bevilge $60.000 \mathrm{kr}$. til Sydslesvigsk Udvalg. Måske var der muligheder dér. Det blev til en rejse til København og en samtale med departementschef J. C. Mogensen fra landbrugsministeriet, som også var stærkt engageret i Sydslesvigsk Udvalg. Han lovede at anbefale mig til en stilling som rejsesekretær i udvalget. Dagen efter havde jeg møde med Sydslesvigsk Udvalgs formand, minister Niels Høst og kontorchef J. Kisbye Møller. Det fik sagen til at falde på plads. Den 1. juni kom ansættelsen som rejsesekretær med arbejdsområde i Ringkøbing og Ribe amter. Dermed afsluttedes mit landmandsliv, og det politiske arbejde blev mere behersket. Nu var det Sydslesvig, der skulle arbejdes for. 
Om udgivelsen

Ovenstående er en bearbejdet og forkortet gengivelse af Fr. Rudbecks erindringer (red. Lars N. Henningsen og Niels H. Kragh-Nielsen). Originalmanuskriptet findes i Fr. Rudbecks arkiv i Arkivet ved Dansk Centralbibliotek for Sydslesvig (arkiv P 357).

Her findes også et stort supplerende materiale, især til belysning af Rudbecks mangeårige kontakt til Sydslesvig. 